\title{
The sources of wage growth in a developing country
}

\author{
loana Marinescu ${ }^{1 *}$ (D) and Margaret Triyana ${ }^{2}$
}

\author{
* Correspondence: \\ ioana.marinescu@gmail.com \\ ${ }^{1}$ University of Chicago, 1155 E. 60th \\ St, Chicago, IL 60637, USA \\ Full list of author information is \\ available at the end of the article
}

\begin{abstract}
What are the sources of wage growth in developing countries? In the USA, general labor market experience is the key source of wage growth, with job seniority playing a smaller role. By contrast, in Indonesia, the 10-year return to seniority is 24 to $28 \%$, which is higher than the return to experience. Furthermore, we estimate a $35 \%$ return to 10 years of tenure in the formal sector, with no significant return to tenure in the informal sector. The difference in the sources of wage growth in Indonesia versus the USA may be a reflection of Indonesia's lower level of development.
\end{abstract}

JEL codes: J3, O1

Keywords: Human capital, Informal labor market, Returns to tenure

\section{Introduction}

Wage growth is tied to general and specific human capital accumulation (Becker, 1964). To further analyze the role of specific human capital, labor economists have estimated the returns to employer, occupation, and industry tenure. In the USA, pioneering work by Altonji and Shakotko (1987) has used an instrumental variable strategy to correct for endogeneity when estimating the returns to employer tenure. Subsequent work has investigated the importance of industry, occupation, and employer-specific human capital in determining wage growth (Altonji and Shakotko, 1987; Parent, 2000; Kambourov and Manovskii, 2009). The most recent work concludes that general labor market experience and occupation tenure are the most important contributors to wage growth in the USA (Kambourov and Manovskii, 2009; Sullivan, 2010).

Little is known about how human capital accumulation affects wage growth in developing countries. A dearth of adequate panel data with labor market histories is to blame for this gap in the literature. This paper contributes to filling this gap by estimating for the first time the returns to potential experience, employer tenure, occupation, and industry in a developing country, Indonesia. Furthermore, when investigating the sources of wage growth in developing countries, it is important to consider the role of the informal sector as a factor that differentiates jobs. Indeed, in developing countries, the informal sector typically employs a large share of the labor force. While the share of workers employed informally is less than $10 \%$ in developed economies, it is as high as $60 \%$ in the developing world (Bacchetta et al., 2009). A job in the same occupation and industry may be quite different and require different skills 
depending on its formality status. For example, let us examine the case of a salesperson in the retail industry. A formal salesperson job will typically be in a larger shop and will consist of assisting wealthier customers and handling credit card purchases. In contrast, an informal salesperson is likely to work on the street, trying to attract customers while at the same time avoiding potential police harassment. More generally, we can expect formal jobs to use a more modern, more capital intensive, production technology. The substantial size of the informal sector and the distinctive characteristics of formal and informal jobs imply that, in addition to employer, occupation, and industry, sector-specific human capital is likely to matter in determining wage growth in developing countries.

Determining whether sector-specific human capital contributes to wage growth in developing countries is important for two reasons. First, formality comes with social benefits, such as minimum wage, health insurance, and pensions. Formal sector workers have to pay taxes to enjoy these social benefits, so the formal sector is unattractive for workers who value these benefits at less than their cost. In addition to these tax disincentives to switching to formality, informal workers may lose their sector-specific human capital when they switch to formality. On the other hand, formal workers may choose to remain formal despite tax disincentives so as to benefit from the returns to their formality-specific human capital. Therefore, estimating the magnitude of sector-specific returns will improve our understanding of workers' sector attachment. Second, estimating the returns to sector tenure is also important to design better public policies. Indeed, when informality is high, governments lose tax revenue and state capacity is eroded. For these reasons, many governments in developing countries are interested in policies that can increase formality. The presence of formality and informality-specific human capital offers both challenges and opportunities for the design of such policies. On the one hand, if there is informality-specific human capital, it will be hard to persuade older informal workers to switch to the formal sector and renounce the benefits of their informality-specific human capital. On the other hand, positive returns to formality-specific human capital open the possibility that a temporary subsidy to formality will yield a persistent long-run increase in formality.

In this paper, we estimate the returns to employer, occupation, industry, and sector tenure in Indonesia. We use the instrument developed by Altonji and Shakotko (1987) and used by Parent (2000) and Kambourov and Manovskii (2009) to estimate returns to tenure using the Indonesian Family Life Survey (IFLS). The panel structure of the data allows us to construct respondents' employment history between 1988 and 2007. We find that the 10-year return to employer tenure is $24 \%$ and the returns to potential experience are $18 \%$. Once we include occupation, industry, and sector tenure, we find that the returns to employer tenure and potential experience remain significant and of similar magnitude, while there is no significant return to sector tenure. However, when we allow the returns in the formal sector to differ from the returns in the informal sector, we find that the returns are much higher in the formal sector. All else equal, the 10 -year return to formal sector tenure is $35 \%$, while there is no significant return to tenure in the informal sector.

This paper makes two key contributions to the literature. First, it provides the first detailed estimates of the return to general and specific human capital for a developing country using an estimation strategy that has been broadly used for developed countries. This allows us to compare the sources of wage growth across developed and 
developing countries. We find that, contrary to what was found for the USA (Altonji and Shakotko, 1987; Altonji and Williams, 2005; Beffy et al., 2006; Sullivan, 2010), the returns to employer tenure are higher than the returns to experience in Indonesia. The fact that the returns to experience are lower in Indonesia than in the USA is consistent with the broader pattern of lower returns to experience in poorer countries uncovered by Lagakos et al. (2012). Furthermore, in Indonesia, the returns to employer tenure are essentially unaffected if we allow for returns to industry and occupation tenure, which is again different from the results found on US data (Kambourov and Manovskii, 2009; Sullivan, 2010). Second, we show that returns to formal sector tenure are very important and are in fact the most important source of wage growth in Indonesia. This result suggests that workers in the formal sector enjoy substantially higher wage growth than their informal counterparts. Policies aiming at increasing the formalization of the economy should take into account the high returns to formal sector tenure; this suggests that incentives for formality should be targeted to younger workers to allow them to acquire formality-specific human capital.

The remainder of the paper is organized as follows. Section 2 presents the institutional background. Section 3 describes the data, and Section 4 describes the estimation strategy. Section 5 presents and discusses the results. Section 6 concludes.

\section{Informality in Indonesia}

It is important to distinguish between formal and informal jobs because the informal sector plays an important role in developing economies like Indonesia. For the purpose of our study, the distinction between formal and informal jobs is important because jobs in the formal sector may require different skills than jobs in the informal sector. In general, the informal sector has been defined in three ways. The International Labour Organisation (ILO) and the Economic Commission for Latin American and the Caribbean define the informal sector as the sum of non-professional self-employed, domestic workers, unpaid workers, and workers in enterprises employing five or fewer workers (Angelini and Hirose, 2004). Second, formal employment can be defined as employment in a job where mandatory social security contributions are paid. Third, formal employment can be defined as employment in firms that are registered.

Indonesia's National Statistics Agency (Badan Pusat Statistik, BPS) uses an enterprise-based approach to define informality. Formal sector enterprises are legal entities of the form listed by the Ministry of Manpower. ${ }^{1}$ The legal status of a company/ unit of economic activity is based on the legal document prepared by a solicitor when the company was established. Enterprises that are registered for tax purposes or operating permit but do not have the legal status in the definitions listed by the Ministry of Manpower are considered informal. The share of the informal sector declined from almost $80 \%$ in 1990 to $60 \%$ right before the 1998 Asian economic crisis, and the share of the informal sector has been about $65 \%$ since 2000 . $^{2}$ According to a 2004 ILO report (based on BPS estimates), about 55 million of the 90 million workforce are in the informal economy, with the majority in agriculture. Excluding the agricultural sector, $47 \%$ of the workforce is in the informal sector. The formal economy is mainly comprised of the following industries: government, mining, construction and utilities, and finance.

The Indonesian Ministry of Manpower (UU Ketenagakerjaan No. 13, 2003) defines informal workers as those with no terms of employment in terms of salary and scope 
of the work. In terms of employment status, casual and unpaid workers are considered informal, while self-employed workers may be in either sector depending on the legal status of the enterprise. The majority of self-employed workers in Indonesia are informal. Maloney (2004) summarizes the characteristics associated with informal selfemployment in developing countries. Self-employment in this setting often appears voluntary. The evidence on the earnings of the informal self-employed is mixed. There is some evidence that some workers earn more in informal self-employment than in salaried employment (Blau, 1985). If not, the self-employed might value the independence, or they do not value the benefits associated with formal employment. We will consider self-employment as part of the informal sector throughout the analysis (see below for more details on how we define informal and formal jobs). Our data unfortunately does not provide the registration status of workers' enterprise, so self-employed workers whose enterprise is registered would be misclassified. This assumption has been made in other studies in Peru (Yamada, 1996) and Mexico (Maloney, 1999).

Workers in the informal sector in Indonesia are de facto not protected by labor laws such as minimum wage and benefits. Benefits include additional income for major religious holidays, usually equal to workers' monthly salary, and health benefits. Health benefits may be in the form of medical allowances or health insurance. Medical allowance gives workers some compensation for some medical expenses, but unlike health insurance, the amount and coverage vary by employer. Health insurance coverage may be obtained through the government or private insurance. The government has several health insurance programs for the military, civil servants, private employees, and the poor. The government manages a health insurance scheme for private employees under the Employees Social Security System, Jamsostek. ${ }^{3}$ The organization was established in 1995 based on a social security law passed in 1992 (UU No. 3, 1992). Jamsostek voluntary enrolment is available to all workers, including informal workers, but this is rarely taken up. As part of the social security law, beginning in 1993, the government mandates employers with more than 10 employees or a monthly payroll exceeding one million Rupiah (approximately USD 110) to provide health benefits through Jamsostek. However, employers may opt out from the scheme by providing comparable or better health benefits. The rule is not strictly enforced, especially for non-registered enterprises or formal enterprises that declare workers as contractors. To extend benefits to the informal sector, the National Social Security System Act, effective from 2004, mandates employers, including the government, to provide social health insurance. The law provides a framework for the development of social security and social assistance to ultimately phase in universal health coverage. However, the health benefits requirement is also not strictly enforced. ${ }^{4}$ Without knowing the legal status of the enterprise, formality in Indonesia can be defined using employment status, the presence of health benefits, and firm size.

\section{Data}

We use all four waves of the Indonesian Family Life Survey (IFLS). The first wave was conducted in 1993, followed by the second wave in 1997, the third wave in 2000, and the fourth one in 2007. The IFLS is the representative of the Indonesian population living in 13 of the nation's 26 provinces in 1993. These 13 provinces represent $83 \%$ of the population. ${ }^{5}$ The IFLS contains rich information on household and individual 
characteristics. Individual characteristics include date of birth, education, marital status, employment status, and characteristics, as well as retrospective employment history. The employment history includes detailed information on first employment and income. Income is broken down into wages and other payments, which include medical benefits and allowances. IFLS1 (1993) included 7224 households. Subsequent waves of the survey sought to re-interview all households in IFLS1 as well as split-off households. Nearly $91 \%$ of IFLS1 households were interviewed in all waves. The high reinterview rates lessen the risk of bias due to non-random attrition.

Following the existing literature on the returns to human capital using panel data, the sample is restricted to male individuals who were ever employed between 1988 and 2007 (since the survey collects respondents' employment history from 1988). We only include male individuals in the analysis because of the selection into labor market participation. Specifically, opportunities in the labor market for men and women tend to be different in developing countries (Mammen and Paxson, 2000). In our sample, women are less likely to have ever worked (68 \% for women vs. $77 \%$ for men) and when women work, they work fewer hours than men (36.4 h for women vs. $41.3 \mathrm{~h}$ for men). We also restrict the sample to respondents with urban residence because rural residents are much more likely to be in agriculture, hence in the informal sector, and we are interested in returns to sector tenure where both sectors are indeed present. Respondents in the analyzed sample were present in at least two consecutive surveys, so we could construct respondents' employment spells in the intervening years. Following Kambourov and Manovskii (2009), we exclude respondents who worked less than $500 \mathrm{~h}$ or had total earnings of zero in a given year. We also exclude those who reported ever being in the military or ever being in agriculture. Kambourov and Manovskii (2009) also exclude those who ever reported self-employment. We do not exclude "ever self-employed" since self-employment is very common in Indonesia (about $45 \%$ of (person-year) observations in our sample are self-employed). We only exclude those who were "currently self-employed". The rationale for excluding the currently selfemployed is that wage determination is different in salaried jobs compared to selfemployed jobs and wages in self-employment may not reflect productivity in the same way as wages in salaried positions.

We define occupations and industries using the one-digit code used in the IFLS. The dataAppendixcontains the description of the occupation and industry codes. ${ }^{6}$ Respondents' occupation and industry came from the employment module, including the retrospective questions in each survey wave. We identify an employer change when respondents indicated that they were not on the same job as the previous year. We then construct employer and industry tenure based on these employer changes. Occupation may change within a spell with the same employer. A more detailed explanation is available in the data Appendix.

Participation in the formal labor market is difficult to identify because our dataset does not contain information on the registration status of the employer. Formality is also a continuum, and smaller firms are more likely to be informal or partially informal (Perry et al., 2007). We construct sector participation based on several variables. Our preferred variable uses information on medical benefits and firm size, and it separates informal workers into self-employed and salaried informal workers. Even though both self-employed workers and salaried informal workers are in the informal sector, there is evidence that urban self- 
employed workers differ in their observed characteristics and have higher earnings than their salaried counterparts (Blau, 1985). The earnings of the self-employed in our dataset are also higher than their salaried counterparts. In addition, the self-employed are older, more likely to be married, and are less educated than salaried workers.

We construct our preferred indicator for informality using a combination of medical benefits and firm size. The availability of medical benefits best captures the concept of formality as firms complying with regulations. However, we do not always observe whether medical benefits are available in the data, so we supplement the informality definition based on medical benefits with a definition based on firm size. Indeed, lack of social benefits and small firm size have been shown to be correlated in other developing countries (Perry et al., 2007).

In our data, workers who reported receiving medical benefits from their employer are coded as formal, and those who did not receive such benefits are coded as informal. If we do not know whether a worker receives medical benefits, we code as formal workers whose firm size is greater than 20, government workers, and military workers, and we code as informal self-employed workers, casual workers, and workers whose firm size is less than 20. By law, firms with more than 10 employees are required to provide medical benefits. However, we use a threshold of 20 employees because the rule may not be strictly enforced, and the IFLS category for firm size is at 20 employees. In our sample, the majority of workers in firms with fewer than 20 employees are in firms with fewer than 10 workers (in some years, the exact number of employees of the firm is reported by respondents). In addition, only $23 \%$ of workers in firms with fewer than 20 employees reported receiving medical benefits, and $58 \%$ of workers in firms with more than 20 employees reported medical benefits. Therefore, we code as formal private sector workers with medical benefits, private sector workers whose medical benefit status is unknown but work in larger firms. We code as informal private sector workers without medical benefits, casual workers, and workers whose firm size is less than 20 and whose medical benefit status is unknown. We find in the data that self-employed respondents are unlikely to report medical benefits regardless of firm size, so we code self-employed workers as informal workers.

We create alternative indicators of informality for robustness. The first alternative definition combines self-employed workers and salaried workers. Under this definition, formal workers are those with medical benefits, or, if no information on medical benefits is available, those whose firm size is greater than 20, government workers, and those in the military. Self-employed workers, casual workers, workers without medical benefits, and workers whose firm size is less than 20 and for whom we do not have information on medical benefits are coded as informal. The second alternative definition of informality does not include information on medical benefits, so we use only firm size and separate workers into three categories: salaried formal, salaried informal, and self-employed workers. The third definition assumes all self-employed workers and workers in firms smaller than 100 employees are informal. The last alternative definition uses information on medical benefits only. Workers reporting medical benefits are coded as formal, while those without medical benefits are informal; we define as missing the formality status of workers for whom information on medical benefits is not available. This last definition is the most restrictive and has the largest fraction of missing values. 


\subsection{Summary statistics}

On any given year, $13 \%$ of workers moved to a new firm or entered self-employment. Figure 1 shows the transition matrix for formal, salaried informal, and self-employed workers in the sample, including those with missing wages or tenure variables. Formal workers are less likely to switch to informality than informal workers are to switch to formality. On any given year, on average, 3.4 \% of formal workers entered informality either as a salaried or self-employed worker. For informal salaried workers, an average of $4 \%$ switched into formality or self-employment. For self-employed workers, an average of $2.4 \%$ switched into either salaried informal or formal work. Changes between sectors indicate mobility between the formal and informal sectors, which is consistent with recent work on sector mobility (Maloney, 2004).

Figure 2 shows hourly wages by employer, occupation, industry, and sector tenure. Earnings in the first year of tenure tend to be higher than earnings in later years, but this may be driven by job switches. On average, earnings in the formal sector are higher than the informal sector. Wage growth appears to be realized after several years of tenure.

Table 1 presents the worker characteristics in the analyzed sample. The analyzed sample has 820 individuals with non-missing employer, occupation, industry, and sector tenure (formal salaried or informal salaried), with a total of 1611 individual-year observations. Hourly wages are in 2007 Rupiah; the overall mean corresponds to Rp. 6700 (USD 0.67). The fraction informal in our sample is $59 \%$, which is higher than ILO's 2004 estimate of $47 \%$ workers in the non-agriculture informal sector. This discrepancy likely arises from measurement error. We do not observe the registration status of the enterprise in our dataset, and we use a more conservative definition of formality based on medical benefits and a higher firm size threshold. The average education in the analyzed sample is 10 years, which is beyond the minimum requirement of 9 years.

Comparing formal and informal workers in our analyzed sample, formal workers earn Rp. 1100 more (USD 0.11) more than their informal counterparts, which corresponds to a $30 \%$ difference. This is consistent with the fact that informal workers are often paid below minimum wage. Furthermore, formal workers are more educated than informal workers. Formal workers also have slightly higher employer, occupation,

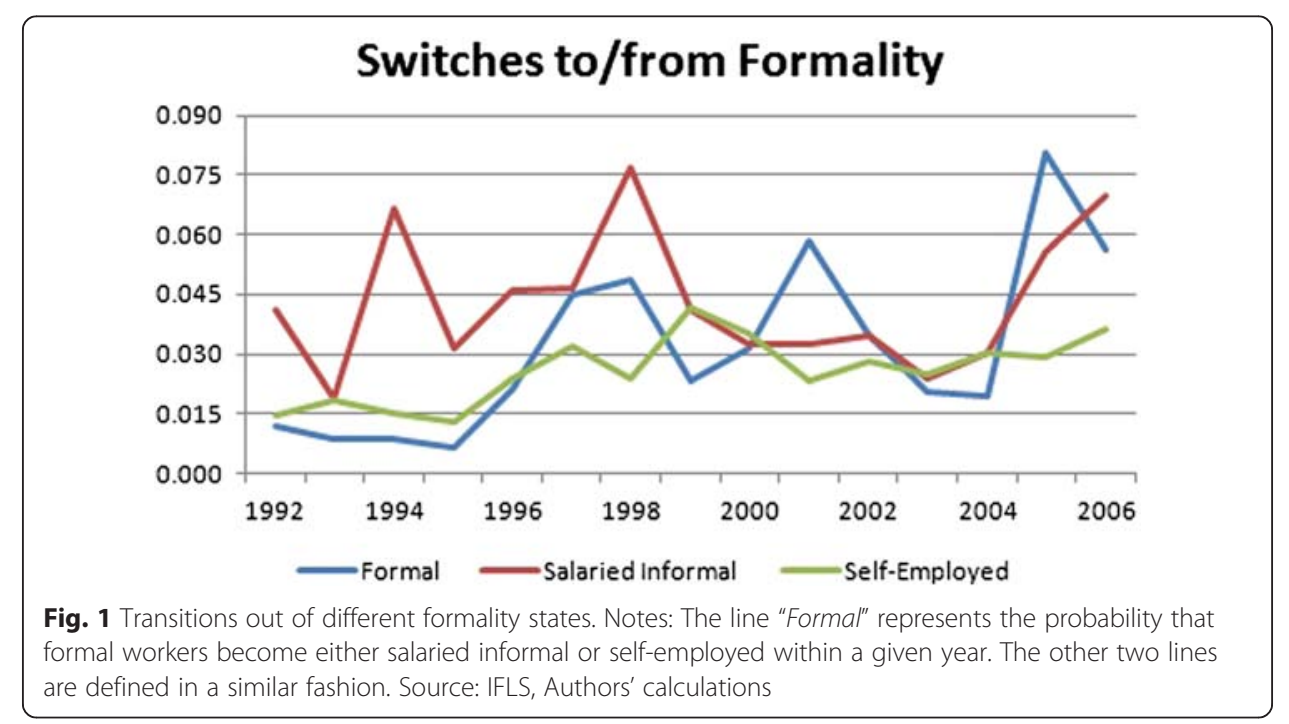




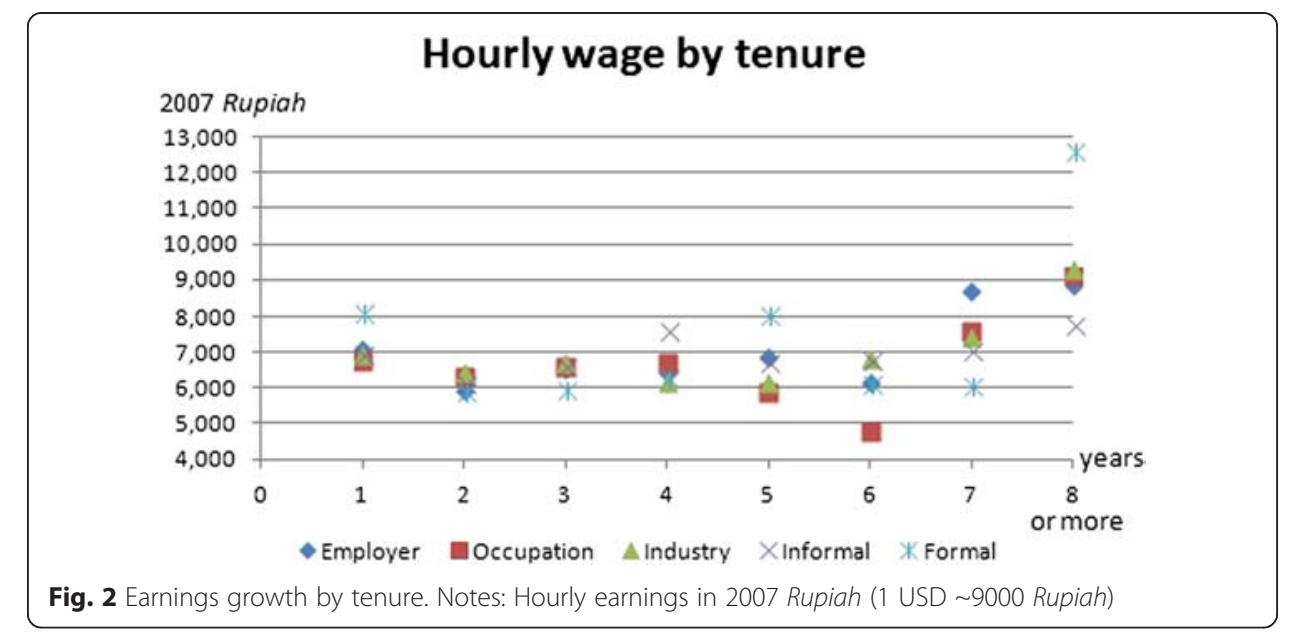

industry, and sector tenure. In this sample, informal workers have higher potential experience, suggesting that they are older than the average formal worker.

\section{Estimation}

Following Kambourov and Manovskii (2009), we will use the following equation to estimate the relationship between wages, employer, occupation, industry, and sector tenure:

$$
\begin{aligned}
\ln _{\text {wage }_{i j m n s t}=} & \boldsymbol{\beta}_{0} \text { emp_ten }_{i j t}+\boldsymbol{\beta}_{1} \boldsymbol{I}\left(\text { emp_ten }_{i j t}>\boldsymbol{1}\right)+\boldsymbol{\beta}_{2} \text { occup_ten }_{i m t} \\
& +\boldsymbol{\beta}_{3} \text { ind_ten }_{\text {int }}+\boldsymbol{\beta}_{4} \text { sector_ten }_{i s t}+\boldsymbol{\beta}_{5} \text { pot_exp }_{i t}+\boldsymbol{\beta}_{6} \boldsymbol{X}_{i \boldsymbol{t}}+\boldsymbol{\mu}_{\boldsymbol{m}} \\
& +\boldsymbol{v}_{\boldsymbol{n}}+\boldsymbol{\tau}_{\boldsymbol{t}}+\epsilon_{\boldsymbol{i}}
\end{aligned}
$$

where $\ln$ wage $_{i j m n s t}$ is the real hourly wage of personiin period $t$ with employer $j$ in occupation $m$, industry $n$, and sectors. emp_ten, occup_ten, ind_ten, and sector_ten are the tenure with the current employer, occupation, industry, and sector, respectively. I(emp_te$\mathrm{n}_{i j t}>1$ ) is an indicator equaling one if the respondent is not in the first year of employ-

\begin{tabular}{|c|c|c|c|c|c|c|}
\hline & \multicolumn{2}{|c|}{ Analyzed sample } & \multicolumn{2}{|l|}{ Formal } & \multicolumn{2}{|c|}{ Informal } \\
\hline & Mean & SD & Mean & SD & Mean & SD \\
\hline Log hourly wages & 8.376 & 0.845 & 8.521 & 0.745 & 8.274 & 0.895 \\
\hline Informal & 0.587 & 0.492 & 0.000 & 0.000 & 1.000 & 0.000 \\
\hline Employer tenure & 3.313 & 2.970 & 3.807 & 3.253 & 2.965 & 2.701 \\
\hline Occupation tenure & 3.199 & 2.912 & 3.411 & 3.048 & 3.051 & 2.804 \\
\hline Industry tenure & 3.996 & 3.441 & 4.400 & 3.656 & 3.712 & 3.253 \\
\hline Sector tenure & 3.634 & 3.114 & 3.748 & 3.240 & 3.554 & 3.021 \\
\hline Potential experience & 10.261 & 10.723 & 9.039 & 8.839 & 11.120 & 11.799 \\
\hline Married & 0.455 & 0.498 & 0.447 & 0.498 & 0.462 & 0.499 \\
\hline Education & 10.858 & 2.991 & 11.595 & 2.507 & 10.339 & 3.189 \\
\hline Province unemployment & 8.055 & 3.641 & 8.602 & 3.667 & 7.670 & 3.575 \\
\hline N & 1616 & & 667 & & 949 & \\
\hline
\end{tabular}
ment with the current employer; this is to allow for different returns to tenure past the

Table 1 Summary statistics

Notes: Log hourly wages are in 2007 Rupiah (1 USD 9000 Rupiah). Tenure variables, education, and potential experience are in years. Province unemployment from the Indonesian National Statistics Agency (BPS) 
first year of employment. pot_exp is the individual's potential experience, calculated as age minus education minus 6 . We also include industry and occupation dummies $\left(\boldsymbol{\mu}_{m}, \boldsymbol{v}_{\boldsymbol{n}}\right)$. Additional characteristics $X_{i t}$ include education, marital status, and province unemployment rate. ${ }^{7}$ We include province fixed effects to capture time-invariant province characteristics and year fixed effects $\left(\boldsymbol{\tau}_{\boldsymbol{t}}\right)$ to capture time-specific shocks. Province unemployment rate is included to capture variation in the local labor market. Some specifications also include the square term of employer tenure and education and the square and cube terms of occupation and industry tenure and potential experience.

The error term $\epsilon_{i t}$ can be decomposed into

$$
\epsilon_{\mathrm{it}}=\boldsymbol{\mu}_{\mathrm{i}}+\boldsymbol{\lambda}_{\mathrm{ij}}+\boldsymbol{\zeta}_{\mathrm{im}}+\boldsymbol{\psi}_{\mathrm{in}}+\boldsymbol{\gamma}_{\mathrm{is}}+\boldsymbol{v}_{\mathrm{it}}
$$

where $\mu_{i}$ is the individual-specific component, $\lambda_{i j}$ is the job match component, $\zeta_{i m}$ is the occupation match component, $\psi_{i n}$ is the industry match component, $\gamma_{i s}$ is the sector match component, and $v_{i t}$ is the error term. These match components are unobserved, and they may affect wages.

We first use ordinary least squares (OLS) to estimate Eq. 1. However, workers with the same observable characteristics may have different wages because of the quality of the match to their employer, occupation, industry, or sector of employment. These unobserved match components are likely to be correlated with the tenure variables and the wages. Workers with higher tenure at their employer or in their occupation, industry, or sector may simply be better matches. For example, a worker who is particularly productive with a specific employer would not want to switch jobs, leading to high employer tenure: such a selection bias implies that OLS overestimates the returns to employer tenure. On the other hand, OLS returns to tenure could also be downward biased if switching employers, occupation, industry, or sector is costly: indeed, in this case, wages in the new job would have to be high enough to compensate for the costs of switching, implying that new jobs are positively selected on wages.

To address this endogeneity problem, we follow the solution proposed by Altonji and Shakotko (1987) and used by Parent (2000) and Kambourov and Manovskii (2009). We use the following instrument for occupational tenure for personiin occupation $m$ at time $t$ :

$$
\widehat{\text { occup_ten }}_{i m t}=\text { occup_ten }_{i m t}=\text { occup_ten }_{i m}
$$

where occup_ten ${ }_{i m}$ is the average tenure of individual $i$ during the current spell of working in occupation $m$. The squared and cubed terms are defined similarly as $\left(\text { occup_ten }_{i m t}\right)^{2}=\left(\text { occup_ten }_{i m t}\right)^{2}-\left(\text { occup_ten }_{i m}\right)^{2}$ and $\left(\text { occup_ten }_{i m t}\right)^{3}=\left(\text { occup_ten }_{i m t}\right)^{3}-$ $\left(\text { occup_ten }_{i m}\right)^{3}$. We use the corresponding instrument for the industry, employer, and sector tenure variables, as well as the indicator for employer tenure greater than 1 , $I\left(\right.$ emp_ten $\left._{i j t}>1\right)$. By construction, the instrument is correlated with the endogenous tenure variable and uncorrelated with the error term. Specifically, the instrument sums up to zero over the sample years in which the worker is in a specific occupation, so it is uncorrelated with the individual and occupation match-specific error component. The instrumental variables (IV) strategy allows us to eliminate the potentially endogenous match-specific component and estimate the returns to employer, occupation, industry, and sector of employment. 


\section{Results}

We start with examining the results to employer tenure and potential labor market experience, following Altonji and Shakotko (1987). We present the OLS results and IV estimates obtained from two stage least squares in Table $2 .^{8}$ The first column presents OLS estimates of the linear model, and the second column presents IV estimates of the linear model. The relationship between wages and employer tenure is positive and significant under both OLS and IV. The relationship between wages and potential experience is also positive and significant. The coefficient on old job (indicator for employer tenure $>1$ ) is negative and significant in this analyzed sample, although it is typically positive in the literature. A positive coefficient is consistent with the quality of the job match being revealed in the first year on the job or investment in job-specific skills happening rapidly at the beginning of a job, especially through training (Kambourov and Manovskii,2009). However, this may not be the case if investment in job-specific skills happens slowly in Indonesia. This may be especially true in the informal sector,

Table 2 Returns to employer tenure

\begin{tabular}{|c|c|c|c|c|}
\hline Dependent variable & (1) & (2) & (3) & (4) \\
\hline$\underline{\text { Log hourly wage }}$ & OLS & IV & OLS & IV \\
\hline \multirow[t]{2}{*}{ Employer tenure } & $0.016^{*}$ & $0.039^{* * *}$ & -0.002 & 0.008 \\
\hline & $(0.009)$ & $(0.011)$ & $(0.024)$ & $(0.029)$ \\
\hline \multirow[t]{2}{*}{ Employer tenure $^{2}$} & & & 0.001 & 0.002 \\
\hline & & & $(0.002)$ & $(0.002)$ \\
\hline \multirow[t]{2}{*}{ Potential experience } & $0.014 * * *$ & $0.013^{* * *}$ & $0.025^{* *}$ & 0.017 \\
\hline & $(0.003)$ & $(0.003)$ & $(0.012)$ & $(0.012)$ \\
\hline \multirow[t]{2}{*}{ Potential experience ${ }^{2}$} & & & -0.000 & 0.000 \\
\hline & & & $(0.001)$ & $(0.001)$ \\
\hline \multirow[t]{2}{*}{ Potential experience ${ }^{3}$} & & & -0.000 & -0.000 \\
\hline & & & $(0.000)$ & $(0.000)$ \\
\hline \multirow[t]{2}{*}{ Employer tenure $>1$} & $-0.123^{* *}$ & $-0.111^{* *}$ & $-0.107^{*}$ & -0.056 \\
\hline & $(0.049)$ & $(0.055)$ & $(0.060)$ & $(0.066)$ \\
\hline \multirow[t]{2}{*}{ Married } & $0.173^{* * *}$ & $0.141^{* * *}$ & $0.132^{* * *}$ & $0.115^{* *}$ \\
\hline & $(0.047)$ & $(0.047)$ & $(0.050)$ & $(0.049)$ \\
\hline \multirow[t]{2}{*}{ Education } & $0.105^{* * *}$ & $0.104^{* * *}$ & $-0.095^{* * *}$ & $-0.100^{* * *}$ \\
\hline & $(0.008)$ & $(0.008)$ & $(0.032)$ & $(0.031)$ \\
\hline \multirow[t]{2}{*}{ Education $^{2}$} & & & $0.010^{* * *}$ & $0.010^{* * *}$ \\
\hline & & & $(0.002)$ & $(0.002)$ \\
\hline Province unemployment & -0.015 & -0.017 & -0.022 & -0.024 \\
\hline Rate & $(0.017)$ & $(0.017)$ & $(0.017)$ & $(0.017)$ \\
\hline Observations & 1616 & 1616 & 1616 & 1616 \\
\hline R-squared & 0.299 & 0.293 & 0.320 & 0.314 \\
\hline \multicolumn{5}{|c|}{ Durbin-Wu-Hausman tests of endogeneity } \\
\hline Chi2 & & 0.008 & & 0.007 \\
\hline $\mathrm{F}$ & & 0.009 & & 0.008 \\
\hline
\end{tabular}

Notes: Robust standard errors in parentheses; ${ }^{* * *} p<0.01,{ }^{* *} p<0.05,{ }^{*} p<0.1$. Occupation, industry, province, and year fixed effects are included. Cols. 3 and 4 include employer tenure squared, potential experience squared and cubed, and education squared 
where there is not much training at the beginning of the employment. Worker demographics also affect wages: the point estimates are similar under OLS and IV. For example, the estimated return to education is about $10 \%$, similar to the estimate for the USA.

We next explore the returns to employer tenure using non-linear terms in tenure. The third and fourth columns of Table 2 presents OLS and IV estimates of the basic model with higher order terms: the squared term of employer tenure, squared and cubed terms of potential experience, and the squared term of years of education. Table 4 shows that the implied returns to 10 years of employer tenure and labor market experience are essentially unaffected by including these higher order terms, and this is true in both the OLS and IV specifications. ${ }^{9}$ The 10-year returns to employer tenure range between 23 and $28 \%$.

Unlike Altonji and Shakotko's estimates, our IV estimates of the returns to employer tenure are higher than our OLS estimates. Why are OLS returns to tenure upward biased in the USA and downward biased in Indonesia? We must remind ourselves that the IV strategy we used corrects for bias due to match-specific components. In the USA, OLS estimates of the returns to employer tenure (after accounting for potential labor market experience) are higher than IV estimates. This suggests that old jobs have higher match-specific components than new jobs: part of the reason why high tenure jobs pay more is that they are better matches. By contrast, in Indonesia, IV estimates of returns to tenure are higher than OLS estimates, suggesting that old jobs have lower match-specific components than new jobs. This would arise if there are high returns to employer tenure or if employer switching is generally costly. Indeed, if there are high returns to employer tenure, there are high opportunity costs to switching employers. Therefore, workers will only switch to a new employer if wages are high enough to compensate them for any costs of employer switching, i.e., the match-specific component in the new job is higher than in the old job. Consistent with the idea that employer switching is costly in Indonesia, job mobility in Indonesia is lower than in the USA or even in Mexico (Maloney, 1999). Overall, OLS estimates are downward biased in Indonesia and upward biased in the USA because employer switching is more costly in Indonesia.

Having examined the returns to employer tenure, we proceed to a more general specification, which allows for returns to additional types of human capital. Table 3 presents the full model: it includes employer, occupation, industry tenure, and sector tenure. The first two columns estimate the model using linear terms only, and the last two columns include higher order terms. Odd columns present OLS estimates and the even columns present IV estimates. We note that, all else equal, being in the informal sector is associated with a $13 \%$ lower wage rate, consistent with prior literature showing that informal jobs tend to pay lower wages (Perry et al., 2007).

In Table 4, we compare the returns to different types of human capital in linear and non-linear specifications by calculating the 10 -year returns based on the coefficients in Tables 2 and 3. Columns 1 to 4 correspond to the models in Table 2, and columns 5 to 8 correspond to models in Table 3. The 10-year return to employer tenure is higher under IV than OLS. When we include occupation, industry, and sector tenure, the returns to employer tenure are less precisely estimated (cols. 6 and 8) but of the same magnitude as in the simpler specification (cols. 2 and 4). The estimated 10-year return 
Table 3 Returns to sector tenure

\begin{tabular}{|c|c|c|c|c|}
\hline Dependent variable & (1) & $(2)$ & (3) & (4) \\
\hline Log hourly wage & OLS & IV & OLS & IV \\
\hline \multirow[t]{2}{*}{ Employer tenure } & 0.010 & $0.038^{* *}$ & -0.007 & 0.006 \\
\hline & $(0.011)$ & $(0.015)$ & $(0.033)$ & $(0.046)$ \\
\hline \multirow[t]{2}{*}{ Employer tenure $^{2}$} & & & 0.002 & 0.003 \\
\hline & & & $(0.002)$ & $(0.003)$ \\
\hline \multirow[t]{2}{*}{ Occupation tenure } & -0.013 & -0.015 & 0.027 & $0.164^{* *}$ \\
\hline & $(0.008)$ & $(0.012)$ & $(0.057)$ & $(0.072)$ \\
\hline \multirow[t]{2}{*}{ Occupation tenure ${ }^{2}$} & & & -0.007 & $-0.029^{* *}$ \\
\hline & & & $(0.010)$ & $(0.012)$ \\
\hline \multirow[t]{2}{*}{ Occupation tenure ${ }^{3}$} & & & 0.000 & $0.001^{* *}$ \\
\hline & & & $(0.000)$ & $(0.001)$ \\
\hline \multirow[t]{2}{*}{ Industry tenure } & 0.005 & 0.009 & $0.130^{* *}$ & 0.108 \\
\hline & $(0.010)$ & $(0.014)$ & $(0.062)$ & $(0.081)$ \\
\hline \multirow[t]{2}{*}{ Industry tenure ${ }^{2}$} & & & $-0.016^{*}$ & -0.013 \\
\hline & & & $(0.009)$ & $(0.011)$ \\
\hline \multirow[t]{2}{*}{ Industry tenure ${ }^{3}$} & & & 0.001 & 0.000 \\
\hline & & & $(0.000)$ & $(0.000)$ \\
\hline \multirow[t]{2}{*}{ Potential experience } & $0.014^{* * *}$ & $0.013^{* * *}$ & $0.020^{*}$ & 0.011 \\
\hline & $(0.003)$ & $(0.003)$ & $(0.012)$ & $(0.013)$ \\
\hline \multirow[t]{2}{*}{ Potential experience ${ }^{2}$} & & & 0.000 & 0.000 \\
\hline & & & $(0.001)$ & $(0.001)$ \\
\hline \multirow[t]{2}{*}{ Potential experience ${ }^{3}$} & & & -0.000 & $-0.000^{*}$ \\
\hline & & & $(0.000)$ & $(0.000)$ \\
\hline \multirow[t]{2}{*}{ Sector tenure } & 0.007 & 0.006 & $-0.122^{* *}$ & $-0.187^{* *}$ \\
\hline & $(0.008)$ & $(0.013)$ & $(0.061)$ & $(0.077)$ \\
\hline Sector tenure ${ }^{2}$ & & & $0.017^{*}$ & $0.027^{* * *}$ \\
\hline \multirow[t]{3}{*}{ Sector tenure ${ }^{3}$} & & & $(0.009)$ & $(0.010)$ \\
\hline & & & -0.001 & $-0.001^{* *}$ \\
\hline & & & $(0.000)$ & $(0.000)$ \\
\hline \multirow[t]{2}{*}{ Employer tenure $>1$} & $-0.130^{* * *}$ & $-0.120^{* *}$ & $-0.126^{*}$ & -0.081 \\
\hline & $(0.049)$ & $(0.056)$ & $(0.070)$ & $(0.076)$ \\
\hline \multirow[t]{2}{*}{ Informal } & $-0.156^{* * *}$ & $-0.132^{* * *}$ & $-0.156^{* * *}$ & $-0.132 * * *$ \\
\hline & $(0.039)$ & $(0.039)$ & $(0.038)$ & $(0.038)$ \\
\hline \multirow[t]{2}{*}{ Married } & $0.171^{* * *}$ & $0.132^{* * *}$ & $0.135^{* * *}$ & $0.112^{* *}$ \\
\hline & $(0.047)$ & $(0.047)$ & $(0.050)$ & $(0.049)$ \\
\hline \multirow[t]{2}{*}{ Education } & $0.101^{* * *}$ & $0.101^{* * *}$ & $-0.103^{* * *}$ & $-0.109^{* * *}$ \\
\hline & $(0.009)$ & $(0.009)$ & $(0.032)$ & $(0.032)$ \\
\hline \multirow[t]{2}{*}{ Education $^{2}$} & & & $0.010^{* * *}$ & $0.010^{* * *}$ \\
\hline & & & $(0.002)$ & $(0.002)$ \\
\hline Province unemployment & -0.016 & -0.018 & -0.020 & -0.023 \\
\hline Rate & $(0.017)$ & $(0.017)$ & $(0.017)$ & $(0.017)$ \\
\hline
\end{tabular}


Table 3 Returns to sector tenure (Continued)

\begin{tabular}{|c|c|c|c|c|}
\hline Observations & 1616 & 1616 & 1616 & 1616 \\
\hline R-squared & 0.306 & 0.298 & 0.331 & 0.320 \\
\hline \multicolumn{5}{|c|}{ Durbin-Wu-Hausman tests of endogeneity } \\
\hline Chi2 & & 0.007 & & 0.000 \\
\hline $\mathrm{F}$ & & 0.008 & & 0.000 \\
\hline
\end{tabular}

Notes: Robust standard errors in parentheses; ${ }^{* *} p<0.01,{ }^{* *} p<0.05,{ }^{*} p<0.1$. Occupation, industry, province, and year fixed effects are included. Cols. 3 and 4 include employer tenure squared, potential experience squared and cubed, sector tenure squared and cubed, and education squared

to potential experience is consistently positive and significant under OLS and IV. The 10-year returns to potential experience are about $13 \%$ under the linear specification and $18 \%$ under the non-linear specification. The returns to occupation, industry, and sector tenure are not statistically significant.

Although we do not find sector tenure to be an important source of wage growth in Indonesia, we suspect that this may mask heterogeneous effects. Indeed, returns to tenure in the formal sector may be larger than returns to tenure in the informal sector. Since formal jobs tend to be in the more modern sectors of the economy, it may be that there is more to learn in these types of jobs compared to informal jobs. To estimate the returns to sector tenure in the formal and informal sectors separately, Table 5 includes an interaction term between sector tenure and an indicator for an informal job. We use the linear specification to facilitate the interpretation of the results. The first column of Table 5 presents OLS results; the second column presents IV results. The relationship between wages and formal sector tenure is positive and significant, while the interaction term between tenure and informality is negative and significant. These estimates suggest that tenure in formality positively affects wage growth.

In Table 6, we compute the 10-year returns to different types of human capital when we allow returns to sector to differ in formal and informal jobs. The first column of

Table 4 10-year returns to tenure

\begin{tabular}{|c|c|c|c|c|c|c|c|c|}
\hline & \multicolumn{4}{|l|}{ Table 2} & \multicolumn{4}{|l|}{ Table 3} \\
\hline & (1) & $(2)$ & (3) & (4) & (5) & (6) & (7) & (8) \\
\hline & OLS & IV & OLS & IV & OLS & IV & OLS & IV \\
\hline \multirow[t]{2}{*}{ Employer } & 0.035 & $0.281^{* *}$ & 0.017 & $0.242^{* *}$ & -0.027 & $0.256^{*}$ & -0.021 & 0.234 \\
\hline & $(0.069)$ & $(0.101)$ & $(0.074)$ & $(0.110)$ & $(0.102)$ & $(0.142)$ & $(0.121)$ & $(0.185)$ \\
\hline \multirow[t]{2}{*}{ Occupation } & & & & & -0.130 & -0.146 & -0.119 & -0.075 \\
\hline & & & & & $(0.081)$ & $(0.120)$ & $(0.084)$ & $(0.127)$ \\
\hline \multirow[t]{2}{*}{ Industry } & & & & & 0.055 & 0.091 & $0.197^{* *}$ & 0.235 \\
\hline & & & & & $(0.100)$ & $(0.144)$ & $(0.130)$ & $(0.202)$ \\
\hline \multirow[t]{2}{*}{ Potential experience } & $0.137^{* * *}$ & $0.129 * * *$ & $0.226^{* *}$ & $0.176^{* *}$ & $0.139^{* * *}$ & $0.128^{* * *}$ & $0.201^{* *}$ & $0.137^{*}$ \\
\hline & $(0.028)$ & $(0.028)$ & $(0.079)$ & $(0.080)$ & $(0.028)$ & $(0.028)$ & $(0.080)$ & $(0.082)$ \\
\hline \multirow[t]{2}{*}{ Sector } & & & & & 0.071 & 0.060 & -0.081 & -0.139 \\
\hline & & & & & $(0.084)$ & $(0.127)$ & $(0.111)$ & $(0.169)$ \\
\hline
\end{tabular}

Notes: Robust standard errors in parentheses; ${ }^{* * *} p<0.01,{ }^{* *} p<0.05,{ }^{*} p<0.1$. Calculations based on coefficients in corresponding columns of Table 2 and Table 3 
Table $\mathbf{5}$ Returns to tenure by sector

\begin{tabular}{|c|c|c|}
\hline Dependent variable & (1) & (2) \\
\hline Log hourly wage & OLS & IV \\
\hline \multirow[t]{2}{*}{ Employer tenure } & 0.005 & $0.026^{*}$ \\
\hline & $(0.011)$ & $(0.015)$ \\
\hline \multirow[t]{2}{*}{ Occupation tenure } & -0.013 & -0.012 \\
\hline & $(0.008)$ & $(0.012)$ \\
\hline \multirow[t]{2}{*}{ Industry tenure } & 0.004 & 0.006 \\
\hline & $(0.010)$ & $(0.014)$ \\
\hline \multirow[t]{2}{*}{ Potential experience } & $0.014^{* * *}$ & $0.013^{* * *}$ \\
\hline & $(0.003)$ & $(0.003)$ \\
\hline \multirow[t]{2}{*}{ Sector tenure } & $0.025^{* *}$ & $0.035^{* *}$ \\
\hline & $(0.010)$ & $(0.015)$ \\
\hline \multirow[t]{2}{*}{ Informal $\times$ sector tenure } & $-0.027^{* *}$ & $-0.044^{* * *}$ \\
\hline & $(0.011)$ & $(0.015)$ \\
\hline \multirow[t]{2}{*}{ Informal } & -0.065 & 0.014 \\
\hline & $(0.058)$ & $(0.063)$ \\
\hline \multirow[t]{2}{*}{ Employer tenure $>1$} & $-0.115^{* *}$ & $-0.104^{*}$ \\
\hline & $(0.049)$ & $(0.056)$ \\
\hline \multirow[t]{2}{*}{ Married } & $0.169^{* * *}$ & $0.132^{* * *}$ \\
\hline & $(0.047)$ & $(0.047)$ \\
\hline \multirow[t]{2}{*}{ Education } & $0.100^{* * *}$ & $0.099^{* * *}$ \\
\hline & $(0.009)$ & $(0.009)$ \\
\hline Province unemployment & -0.016 & -0.018 \\
\hline Rate & $(0.017)$ & $(0.017)$ \\
\hline Observations & 1616 & 1616 \\
\hline R-squared & 0.309 & 0.301 \\
\hline \multicolumn{3}{|c|}{ Durbin-Wu-Hausman tests of endogeneity } \\
\hline \multicolumn{2}{|l|}{ Chi2 } & 0.006 \\
\hline \multicolumn{2}{|l|}{$F$} & 0.007 \\
\hline
\end{tabular}

Notes: Robust standard errors in parentheses; ${ }^{* * *} p<0.01,{ }^{* *} p<0.05,{ }^{*} p<0.1$. Occupation, industry, province, and year fixed effects are included

Table 6 presents 10-year returns under OLS, and column 2 presents IV estimates; these estimates are based on the coefficients in Table 5. In the formal sector, under OLS, there is a $25 \%$ return to sector tenure. Under IV, the estimated 10-year return to formal sector tenure is $35 \%$. Consistent with earlier results, the estimated return to potential experience is 14 and $13 \%$ under OLS and IV, respectively. There are no statistically significant returns to employer, occupation, or industry tenure under either OLS or IV. The fact that we find no significant returns to employer tenure when accounting for returns to tenure in the formal sector suggests that some of the wage growth due to employer tenure is really wage growth associated with tenure in the formal sector. On the other hand, in the informal sector, the 10-year returns to sector tenure are small and not statistically significant under either OLS or IV. Overall, although we find no significant returns to sector tenure in general, returns to formal sector tenure are 
Table 6 10-year returns by sector

\begin{tabular}{llc}
\hline & $(1)$ & $(2)$ \\
\hline Employer & OLS & IV \\
Occupation & -0.067 & 0.158 \\
& $(0.101)$ & $(0.142)$ \\
Industry & -0.126 & -0.116 \\
& $(0.080)$ & $(0.120)$ \\
Potential experience & 0.043 & 0.060 \\
& $(0.099)$ & $(0.143)$ \\
Formal & $0.140^{* * *}$ & $0.132^{* * *}$ \\
& $(0.028)$ & $(0.028)$ \\
Informal & $0.247^{* *}$ & $0.352^{* *}$ \\
& $(0.104)$ & $(0.154)$ \\
& -0.023 & -0.085 \\
\hline
\end{tabular}

Notes: Robust standard errors in parentheses; ${ }^{* * *} p<0.01,{ }^{* *} p<0.05,{ }^{*} p<0.1$. Calculations based on coefficients in corresponding columns of Table 5

* show the statistical significance levels

significant. This provides evidence that formal jobs use more specific skills than informal jobs.

To summarize our results about the returns to different types of specific human capital, we find a strong return to tenure in the formal sector, but no significant return to tenure in the informal sector. Our estimates of 10-year returns to employer, occupation, industry, and sector tenure indicate that formal sector tenure matters more than other specific human capital, namely employer or occupation tenure. In addition to the strong return to formal sector tenure, we find significant returns to potential experience with and without controlling for sector tenure, which is consistent with previous findings in the literature.

In Table 7, we compare our findings to earlier estimates in the literature. Our estimated returns to employer tenure in a specification that does not include other sources of specific human capital are in the high range compared to what was found before. Our estimates are similar to US estimates of returns to employer tenure by Topel (1991) and Beffy et al. (2006) (panel A). Our estimated return to potential experience is lower than estimates for the USA, UK, France, and Germany. Indeed, within these developed countries, estimated returns to potential experience range from 25 to $82 \%$ (Altonji and Williams, 2005; Dustmann and Pereira, 2007; Beffy et al., 2006). Since Lagakos et al. (2012) find that the returns to experience are lower in developing countries, it is plausible that our relatively low estimate of $13 \%$ reflects differences between a developing country and developed countries.

In panel B of Table 7, we compare our estimates for the returns to different types of specific human capital to earlier estimates. In contrast to prior estimates for the USA, we do not find a positive return to occupation tenure. Although noisy, our point estimate on the return to industry tenure is in line with earlier estimates. We conclude that in Indonesia, returns to formal sector employment play a key role in wage growth and returns to other types of specific capital are much lower. 
Table 7 Comparison to previous literature

\begin{tabular}{|c|c|c|c|c|c|c|c|c|}
\hline \multicolumn{9}{|l|}{ Panel A. } \\
\hline & (1) & (2) & (3) & (4) & (5) & (6) & (7) & (8) \\
\hline & $\begin{array}{l}\text { Marinescu and } \\
\text { Triyana (2016) }\end{array}$ & $\begin{array}{l}\text { Altonji and } \\
\text { Shakotko (1987) }\end{array}$ & Topel (1991) & $\begin{array}{l}\text { Altonji and } \\
\text { Williams (2005) }\end{array}$ & $\begin{array}{l}\text { Dustmann and } \\
\text { Pereira (2005) }\end{array}$ & $\begin{array}{l}\text { Dustmann and } \\
\text { Pereira (2005) }\end{array}$ & Beffy et al. (2006) & $\begin{array}{l}\text { Beffy et al. } \\
(2006)\end{array}$ \\
\hline & Indonesia & USA & USA & USA & UK & Germany & USA & France \\
\hline Employer & 0.242 & 0.074 & 0.246 & 0.130 & $.054 \mathrm{NS}$ & -0.004 NS & 0.347 & -0.002 NS \\
\hline Potential experience & 0.176 & 0.364 & & 0.372 & 0.821 & 0.347 & 0.246 & 0.458 \\
\hline \multicolumn{9}{|l|}{ Panel B. } \\
\hline & (1) & (2) & (3) & (4) & (5) & & & \\
\hline & $\begin{array}{l}\text { Marinescu and } \\
\text { Triyana (2016) }\end{array}$ & Parent (2000) & Parent (2000) & $\begin{array}{l}\text { Kambourov and } \\
\text { Manovskii (2009) }\end{array}$ & Sullivan (2010) & & & \\
\hline & 10 years & NLSY & PSID & 8-years & 5-years & & & \\
\hline Employer & 0.158 NS & & & $0.006 \mathrm{NS}$ & -0.059 & & & \\
\hline Occupation & $-0.116 \mathrm{NS}$ & & & 0.111 & 0.133 & & & \\
\hline Industry & 0.060 NS & 0.131 & 0.093 & 0.063 & 0.049 & & & \\
\hline Potential experience & 0.132 & & & & 0.236 & & & \\
\hline Formal sector & 0.352 & & & & & & & \\
\hline Informal sector & $-0.085 \mathrm{NS}$ & & & & & & & \\
\hline
\end{tabular}

Notes: NS not significant, Panel A presents estimated returns to employer tenure and potential experience, Panel B presents estimated returns to employer, occupation, industry, and sector tenure 
Table 8 Returns by sector using alternative definitions of informality

\begin{tabular}{|c|c|c|c|c|c|c|c|c|}
\hline \multirow{3}{*}{$\begin{array}{l}\text { Dependent variable } \\
\text { Log hourly wage }\end{array}$} & (1) & (2) & (3) & (4) & (5) & (6) & (7) & (8) \\
\hline & \multicolumn{2}{|c|}{$\begin{array}{l}\text { Informal: self-employed and salaried } \\
\text { informal in same category }\end{array}$} & \multicolumn{2}{|c|}{$\begin{array}{l}\text { Informal: not using information on } \\
\text { medical benefits }\end{array}$} & \multicolumn{2}{|c|}{$\begin{array}{l}\text { Informal: all self-employed } \\
\text { and small firms }\end{array}$} & \multicolumn{2}{|c|}{$\begin{array}{l}\text { Informal: based on medical } \\
\text { benefits only }\end{array}$} \\
\hline & OLS & IV & OLS & IV & OLS & IV & OLS & IV \\
\hline \multirow[t]{2}{*}{ Employer tenure } & 0.007 & $0.033^{* *}$ & 0.017 & $0.031^{*}$ & 0.007 & 0.021 & 0.007 & -0.004 \\
\hline & $(0.011)$ & $(0.016)$ & $(0.013)$ & $(0.018)$ & $(0.011)$ & $(0.015)$ & $(0.013)$ & $(0.016)$ \\
\hline \multirow[t]{2}{*}{ Occupation tenure } & $-0.018^{* *}$ & -0.014 & -0.014 & -0.004 & -0.010 & -0.006 & $-0.017^{*}$ & -0.011 \\
\hline & $(0.008)$ & $(0.012)$ & $(0.008)$ & $(0.013)$ & $(0.008)$ & $(0.012)$ & $(0.010)$ & $(0.014)$ \\
\hline \multirow[t]{2}{*}{ Industry tenure } & 0.008 & 0.009 & 0.016 & 0.012 & 0.002 & 0.001 & 0.001 & 0.027 \\
\hline & $(0.011)$ & $(0.015)$ & $(0.010)$ & $(0.015)$ & $(0.010)$ & $(0.014)$ & $(0.014)$ & $(0.019)$ \\
\hline \multirow[t]{2}{*}{ Potential experience } & $0.015^{* * *}$ & $0.014^{* * *}$ & $0.013^{* * *}$ & $0.012^{* * *}$ & $0.013^{* * *} 0$ & $.013^{* * *}$ & 0.004 & 0.001 \\
\hline & $(0.003)$ & $(0.003)$ & $(0.003)$ & $(0.003)$ & $(0.003)$ & $(0.003)$ & $(0.004)$ & $(0.004)$ \\
\hline \multirow[t]{2}{*}{ Sector tenure } & $0.020^{*}$ & 0.021 & -0.007 & -0.001 & $0.018^{*}$ & $0.034^{* *}$ & $0.034^{* * *}$ & $0.027^{*}$ \\
\hline & $(0.011)$ & $(0.015)$ & $(0.013)$ & $(0.019)$ & $(0.010)$ & $(0.015)$ & $(0.012)$ & $(0.015)$ \\
\hline \multirow[t]{2}{*}{ Informal $\times$ tenure } & $-0.033^{* * *}$ & $-0.047^{* * *}$ & -0.000 & -0.008 & $-0.026^{* *}$ & $-0.036^{* *}$ & $-0.040^{* * *}$ & $-0.041^{* *}$ \\
\hline & $(0.012)$ & $(0.015)$ & $(0.012)$ & $(0.016)$ & $(0.011)$ & $(0.015)$ & $(0.014)$ & $(0.018)$ \\
\hline \multirow[t]{2}{*}{ Informal } & -0.030 & 0.040 & $-0.116^{*}$ & -0.075 & -0.080 & -0.029 & -0.063 & -0.042 \\
\hline & $(0.060)$ & $(0.065)$ & $(0.062)$ & $(0.069)$ & $(0.058)$ & $(0.061)$ & $(0.081)$ & $(0.082)$ \\
\hline \multirow[t]{2}{*}{ Employer tenure > 1} & $-0.128^{* *}$ & $-0.114^{* *}$ & $-0.134^{* * *}$ & $-0.114^{* *}$ & $-0.102^{* *}$ & $-0.099^{*}$ & $-0.156^{* *}$ & -0.087 \\
\hline & $(0.050)$ & $(0.057)$ & $(0.050)$ & $(0.057)$ & $(0.049)$ & $(0.056)$ & $(0.072)$ & $(0.078)$ \\
\hline \multirow[t]{2}{*}{ Married } & $0.157^{* * *}$ & $0.120^{* *}$ & $0.164^{* * *}$ & $0.135^{* * *}$ & $0.175^{* * *}$ & $0.139^{* * *}$ & $0.275^{* * *}$ & $0.241^{* * *}$ \\
\hline & $(0.048)$ & $(0.049)$ & $(0.047)$ & $(0.047)$ & $(0.047)$ & $(0.047)$ & $(0.061)$ & $(0.061)$ \\
\hline \multirow[t]{2}{*}{ Education } & $0.106^{* * *}$ & $.105^{* * *}$ & $0.096^{* * *}$ & $0.096^{* * *}$ & $0.098^{* * *}$ & $0.097^{* * *}$ & $0.108^{* * *}$ & $0.107^{* * *}$ \\
\hline & $(0.009)$ & $(0.009)$ & $(0.008)$ & $(0.008)$ & $(0.008)$ & $(0.008)$ & $(0.012)$ & $(0.012)$ \\
\hline Province unemployment & -0.011 & -0.013 & -0.005 & -0.007 & -0.011 & -0.015 & 0.002 & -0.002 \\
\hline
\end{tabular}


Table 8 Returns by sector using alternative definitions of informality (Continued)

\begin{tabular}{|c|c|c|c|c|c|c|c|c|}
\hline Rate & $(0.017)$ & $(0.017)$ & $(0.017)$ & $(0.017)$ & $(0.017)$ & $(0.017)$ & $(0.021)$ & $(0.021)$ \\
\hline Observations & 1513 & 1513 & 1575 & 1575 & 1615 & 1615 & 945 & 945 \\
\hline R-squared & 0.327 & 0.319 & 0.292 & 0.287 & 0.303 & 0.296 & 0.337 & 0.333 \\
\hline \multicolumn{9}{|c|}{ Durbin-Wu-Hausman tests of endogeneity } \\
\hline Ch i 2 & & 0.0013 & & 0.0893 & & 0.0359 & & 0.1921 \\
\hline $\mathrm{F}$ & & 0.0016 & & 0.1003 & & 0.0409 & & 0.2142 \\
\hline
\end{tabular}


For robustness, Table 8 presents results using alternative definitions of informality. We also use the linear specification from Table 5 to facilitate the interpretation of the results. Columns 1 and 2 use information on medical benefits and firm size, but we combine selfemployed and salaried informal workers into the same category. Columns 3 and 4 do not use information on medical benefits, but only firm size to define salaried informality. Columns 5 and 6 assume all self-employed and workers in firms with less than 100 employees are informal. Columns 7 and 8 only use medical benefits to define informality. The 10-year returns calculated in Table 9 correspond to the columns in Table 8 . The sample size is notably smaller in this table, especially in columns 7 and 8 . These estimates are noisier compared to results in Table 5 , but the results are generally similar.

The estimates of 10-year returns to different types of human capital using alternative definitions of informality are presented in Table 9. These estimates are noisy, but they are for the most part qualitatively similar to our earlier estimates using our preferred definition presented in Table 6. Estimated 10-year returns to employer, occupation, and industry tenure are not significant under any of the alternative definitions. On the other hand, the point estimates of returns to employer tenure for two alternative definitions of informality (cols. 2 and 6) are positive and very similar in magnitude to our main specification. The returns to employer tenure using the final definition of informality based on medical benefits only are smaller, but they may be hard to estimate given a much smaller and selected sample size (col. 8). As for returns to sector tenure, IV estimates of 10-year returns in the formal sector are similar in magnitude to our main estimates, except for the definition of informality that does not use medical benefits (col. 4). Using medical benefits only, the estimated 10-year return in the formal sector is a significant $27 \%$, similar to our estimate of $35 \%$ using the preferred definition of formality.

The definition of informality and formality matters for the estimation of returns to sector tenure. Specifically, we find that firm size is not a very good proxy for formality. It is true that firm size is highly predictive of benefit provision, with larger firms more likely to provide benefits, but there are still plenty of small firms that are formal and large firms that are informal if informality is defined according to health benefit provision. Indeed, among observations used to estimate regressions underlying column 4 (Table 8 ), we find that $14 \%$ of very small firms (4 workers or fewer) provide health benefits and are therefore formal according to this definition, while $22 \%$ of very large firms (100 workers or more) do not provide health benefits and are therefore informal.

\section{Conclusions}

In this paper, we have shown that returns to employer tenure in Indonesia are higher than in the USA and other developed countries. By contrast, returns to experience are lower in Indonesia than in developed countries. Furthermore, in Indonesia, returns to employer tenure are larger than returns to experience, and our estimates of returns to employer tenure are unaffected when we account for returns to other types of human capital, such as occupation and industry-specific human capital. As in many developing countries, informality is quite prevalent in Indonesia. We test for returns to sector-specific human capital and find that only formality offers positive returns. Overall, we conclude that employer tenure and formal sector tenure are the main sources of wage growth in Indonesia, with general labor market experience playing a smaller but significant role. 
Table 9 10-year returns using alternative definitions of informality

\begin{tabular}{|c|c|c|c|c|c|c|c|c|}
\hline & (1) & $(2)$ & (3) & (4) & (5) & (6) & (7) & (8) \\
\hline & \multicolumn{2}{|c|}{$\begin{array}{l}\text { Informal: self-employed and } \\
\text { salaried informal in same category }\end{array}$} & \multicolumn{2}{|c|}{$\begin{array}{l}\text { Informal: not using information } \\
\text { on medical benefits }\end{array}$} & \multicolumn{2}{|c|}{$\begin{array}{l}\text { Informal: all self-employed } \\
\text { and small firms }\end{array}$} & \multicolumn{2}{|c|}{$\begin{array}{l}\text { Informal: based on } \\
\text { medical benefits only }\end{array}$} \\
\hline & OLS & IV & OLS & IV & OLS & IV & OLS & IV \\
\hline \multirow[t]{2}{*}{ Employer } & -0.061 & 0.218 & 0.036 & 0.196 & -0.028 & 0.114 & -0.089 & -0.128 \\
\hline & $(0.105)$ & $(0.149)$ & $(0.118)$ & $(0.170)$ & $(0.099)$ & $(0.140)$ & $(0.117)$ & $(0.145)$ \\
\hline \multirow[t]{2}{*}{ Occupation } & $-0.181^{* *}$ & -0.136 & -0.136 & -0.037 & -0.097 & -0.056 & $-0.166^{*}$ & -0.110 \\
\hline & $(0.083)$ & $(0.125)$ & $(0.083)$ & $(0.125)$ & $(0.080)$ & $(0.119)$ & $(0.098)$ & $(0.138)$ \\
\hline \multirow[t]{2}{*}{ Industry } & 0.082 & 0.092 & 0.163 & 0.125 & 0.018 & 0.009 & 0.013 & 0.266 \\
\hline & $(0.108)$ & $(0.152)$ & $(0.104)$ & $(0.146)$ & $(0.100)$ & $(0.141)$ & $(0.141)$ & $(0.186)$ \\
\hline \multirow[t]{2}{*}{ Potential experience } & $0.150^{* * *}$ & $0.139^{* * *}$ & $0.126^{* * *}$ & $0.120^{* * *}$ & $0.135^{* * *}$ & $0.127^{* * *}$ & 0.038 & 0.012 \\
\hline & $(0.031)$ & $(0.030)$ & $(0.027)$ & $(0.027)$ & $(0.028)$ & $(0.027)$ & $(0.037)$ & $(0.039)$ \\
\hline \multirow[t]{2}{*}{ Formal } & $0.197^{*}$ & 0.206 & -0.070 & -0.006 & $0.183^{*}$ & $0.344^{* *}$ & $0.343^{* *}$ & $0.265^{*}$ \\
\hline & $(0.107)$ & $(0.152)$ & $(0.133)$ & $(0.193)$ & $(0.103)$ & $(0.148)$ & $(0.118)$ & $(0.147)$ \\
\hline \multirow[t]{2}{*}{ Informal } & -0.137 & $-0.265^{* *}$ & -0.073 & -0.089 & -0.080 & -0.014 & -0.056 & -0.145 \\
\hline & $(0.098)$ & $(0.132)$ & $(0.113)$ & $(0.157)$ & $(0.091)$ & $(0.126)$ & $(0.123)$ & $(0.142)$ \\
\hline
\end{tabular}


From a policy perspective, our results suggest that, for countries that wish to increase the prevalence of formal employment, it may be effective to offer incentives to young people to be employed formally. Indeed, we have found that there are high returns to tenure in the formal sector of the economy. Therefore, once someone has been working in formal jobs for a while, positive returns to tenure in the formal sector make it less attractive to switch to the informal sector, even in the absence of government provided incentives. This implies that a temporary incentive to work formally may permanently increase the level of formality in a country.

By examining the sources of wage growth in Indonesia, we have found that they are quite different from the sources of wage growth in developed countries. Additional research is required to determine whether this pattern is specific to Indonesia or is more generally prevalent across other developing countries. Future research should also investigate the reasons why sources of wage growth in developing countries such as Indonesia differ from sources of wage growth in developed countries. Such an investigation is fundamental to further our understanding of income growth in developing countries.

\section{Endnotes}

${ }^{1}$ Legal status can take the form of PN, Perum, Perusahaan Daerah/PD (different types of government-owned enterprise), PT, PT/NV, CV, Firma (different types of limited liability firms), Koperasi (cooperative), and Yayasan (foundation). In 1996, the definition of legal status is expanded to include SIPD (for quarrying), Diparda (regional government enterprise), and enterprises with a Governor/Bupati (Head of the Regency)/Mayor permit or decision.

${ }^{2} 2010$ ILO Report (http://www.ilo.org/wcmsp5/groups/public/-asia/-ro-bangkok/— ilo-jakarta/documents/publication/wcms_145402.pdf)

${ }^{3}$ Jaminan Sosial Tenaga Kerja

${ }^{4}$ By 2005, the government health insurance scheme Jamsostek covered less than $5 \%$ of eligible workers (workers employed by legal entities, i.e., formal sector), and only about 4 million of the 56 million in the workforce reported having private health insurance (Setiana2010).

${ }^{5}$ The IFLS provinces include Jakarta, West Java, Central Java, Yogyakarta, East Java, Bali, West Nusa Tenggara, South Kalimantan, South Sulawesi, North Sumatra, West Sumatra, South Sumatra, and Lampung. Fourteen provinces were excluded due to cost considerations given the size and terrain of the country. The eastern provinces of East Nusa Tenggara, East Timor, Maluku and Irian Jaya were excluded due to the cost of fieldwork in these more remote provinces. East Timor is now an independent state. Aceh was excluded out of concern for the area's political violence.

${ }^{6}$ Conditional on our sample selection criteria, the overwhelming majority of workers have non-missing employer tenure. However, occupation and industry tenure are missing for about half of the sample (see Figure A.1). We compare the estimated returns using the non-restricted sample of 5138 observations and the analyzed sample in the sample below and find that the returns to employer tenure (17 vs. $24 \%$ using the analyzed sample) and potential experience are slightly lower (12 vs. $18 \%$ using the analyzed sample), but they are within the confidence intervals of the estimates of our analyzed sample.

${ }^{7}$ Results without these controls are qualitatively similar. 
${ }^{8}$ First-stage results are available in the Appendix.

${ }^{9}$ The returns to employer tenure are calculated as $10 \times \beta+\gamma$, where $\beta$ is the tenure coefficient and $\gamma$ is the coefficient on the indicator for employer $>1$ year. Returns to potential experience (and other tenure variables) are given by $10 \times \beta$, where $\beta$ is the coefficient on potential experience (and other tenure variables).

${ }^{10} \mathrm{http}: / /$ www.stata.com/support/faqs/data/panel.html

${ }^{11}$ Although firms with more than workers are required to provide medical benefits, and should be formal, we find that self-employed people with 10 or more workers report no medical benefits. Thus, self-employed workers with more than 10 workers are still considered informal in this dataset. The results are not sensitive to this difference in definition.

${ }^{12} 70 \%$ of workers in firms with fewer than 20 workers are in firms with 10 or fewer workers.

\section{Appendix}

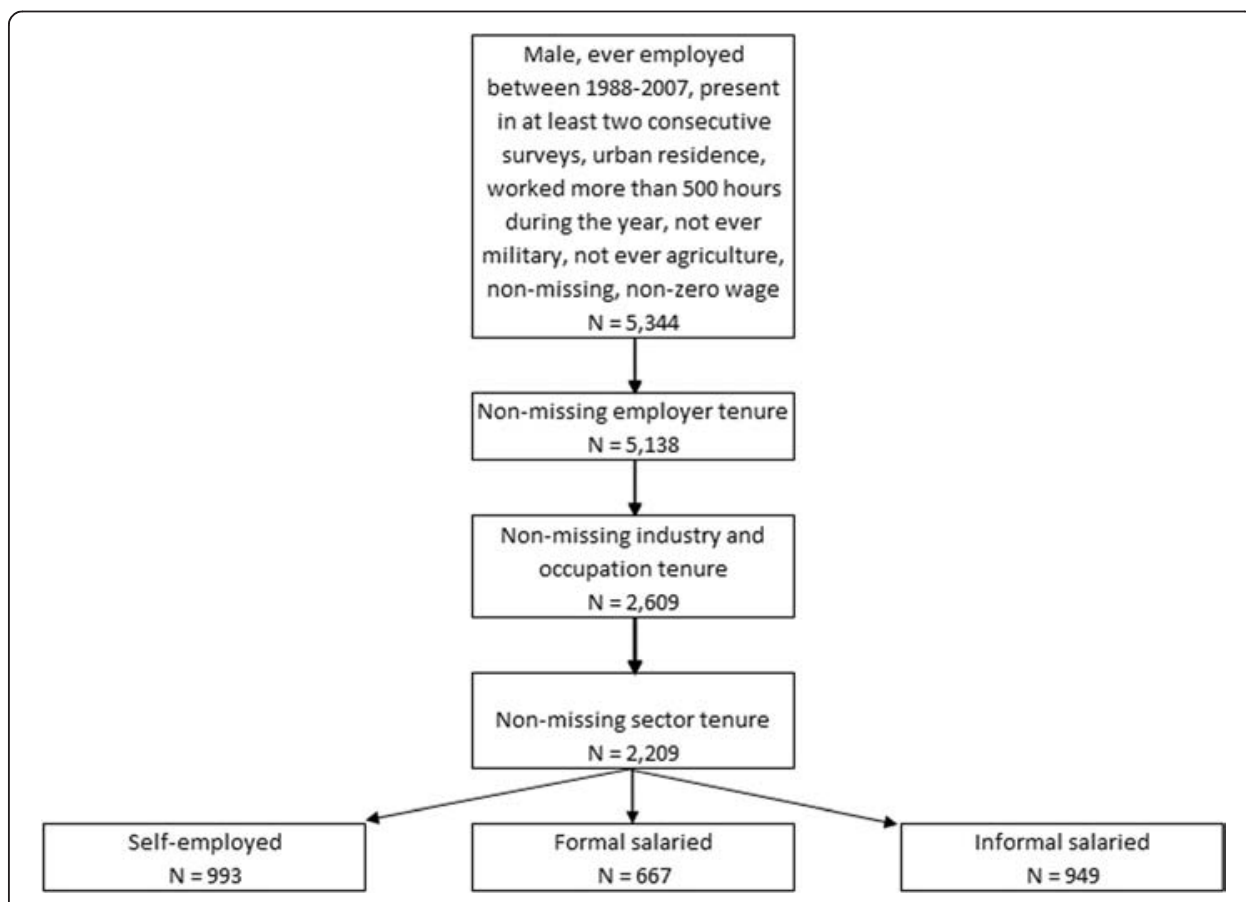

Fig. 3 Sample selection. Notes: Tenure variables include employer, occupation, industry, and sector tenure. The analyzed sample includes formal salaried and informal salaried workers

Table 10 Sample selection: non-missing employer tenure and non-missing industry and occupation tenure

\begin{tabular}{lllllll}
\hline & Log hourly wages & Formal & Potential experience & Age & Married & Education \\
\hline Non-missing industry, & -0.008 & 0.011 & $-0.012^{* * *}$ & $-0.013^{* * *}$ & $-0.290^{* * *}$ & $0.020^{* * *}$ \\
occupation tenure & $(0.009)$ & $(0.016)$ & $(0.001)$ & $(0.001)$ & $(0.014)$ & $(0.002)$ \\
\hline
\end{tabular}

Notes: We restrict the sample to respondents with non-missing employer tenure, resulting in 5138 observations. The next restriction is non-missing industry and occupation tenure. This results in 2609 observations. Robust standard errors in parentheses; ${ }^{* * *} p<0.01,{ }^{* *} p<0.05,{ }^{*} p<0.1$. 
Table 11 First-stage regressions: returns to employer tenure

\begin{tabular}{|c|c|c|c|}
\hline \multicolumn{4}{|l|}{ Panel A. Linear model } \\
\hline \multirow[t]{2}{*}{ Endogenous variable } & (1) & \multicolumn{2}{|l|}{$(2)$} \\
\hline & Employer tenure & \multicolumn{2}{|l|}{ Employer tenure > } \\
\hline \multirow[t]{2}{*}{ Employer tenure } & $0.690^{* * *}$ & \multicolumn{2}{|l|}{$-0.012^{* * *}$} \\
\hline & $(0.027)$ & \multicolumn{2}{|l|}{$(0.003)$} \\
\hline \multirow[t]{2}{*}{ Potential experience } & $0.034^{* * *}$ & \multicolumn{2}{|l|}{$0.003^{* * *}$} \\
\hline & $(0.004)$ & \multicolumn{2}{|l|}{$(0.001)$} \\
\hline \multirow[t]{2}{*}{ Employer tenure >1 } & $0.437^{* * *}$ & \multicolumn{2}{|l|}{$0.988^{* * *}$} \\
\hline & $(0.091)$ & \multicolumn{2}{|l|}{$(0.009)$} \\
\hline \multirow[t]{2}{*}{ Married } & $0.835^{* * *}$ & \multicolumn{2}{|l|}{$0.101^{* * *}$} \\
\hline & $(0.075)$ & \multicolumn{2}{|l|}{$(0.012)$} \\
\hline \multirow[t]{2}{*}{ Education } & $0.033^{* * *}$ & \multicolumn{2}{|l|}{$0.003^{* *}$} \\
\hline & $(0.011)$ & \multicolumn{2}{|l|}{$(0.002)$} \\
\hline Province unemployment & 0.010 & \multicolumn{2}{|l|}{-0.005} \\
\hline Rate & $(0.027)$ & \multicolumn{2}{|l|}{$(0.004)$} \\
\hline R-squared & 0.541 & \multicolumn{2}{|l|}{0.62} \\
\hline F-statistic & 29.91 & \multicolumn{2}{|l|}{131.88} \\
\hline \multicolumn{4}{|l|}{ Panel B. Non-linear model } \\
\hline \multirow[t]{2}{*}{ Endogenous variable } & (1) & (2) & (3) \\
\hline & Employer tenure & Employer tenure $^{2}$ & Employer tenure $>1$ \\
\hline \multirow[t]{2}{*}{ Employer tenure } & $0.678^{* * *}$ & $-2.546^{*}$ & $-0.024^{* * *}$ \\
\hline & $(0.090)$ & $(1.385)$ & $(0.006)$ \\
\hline Employer tenure $^{2}$ & 0.001 & $0.895^{* * *}$ & $0.001^{* *}$ \\
\hline & $(0.007)$ & $(0.115)$ & $(0.000)$ \\
\hline Potential experience & $0.140^{* * *}$ & $1.378^{* * *}$ & $0.020^{* * *}$ \\
\hline & $(0.015)$ & $(0.179)$ & $(0.003)$ \\
\hline Potential experience ${ }^{2}$ & $-0.003^{* * *}$ & $-0.027^{* * *}$ & $-0.001^{* * *}$ \\
\hline & $(0.001)$ & $(0.007)$ & $(0.000)$ \\
\hline Potential experience ${ }^{3}$ & $0.000^{* * *}$ & $0.000^{*}$ & $0.000^{* * *}$ \\
\hline & $(0.000)$ & $(0.000)$ & $(0.000)$ \\
\hline Employer tenure >1 & $0.425^{* * *}$ & $5.508^{* * *}$ & $1.003^{* * *}$ \\
\hline & $(0.137)$ & $(1.987)$ & $(0.012)$ \\
\hline Married & $0.523^{* * *}$ & $5.869^{* * *}$ & $0.060^{* * *}$ \\
\hline & $(0.082)$ & $(0.968)$ & $(0.014)$ \\
\hline Education & $0.164^{* * *}$ & $2.236^{* * *}$ & $0.012^{*}$ \\
\hline & $(0.038)$ & $(0.454)$ & $(0.006)$ \\
\hline Education ${ }^{2}$ & $-0.007^{* * *}$ & $-0.097^{* * *}$ & -0.000 \\
\hline & $(0.002)$ & $(0.023)$ & $(0.000)$ \\
\hline Province unemployment & 0.014 & 0.319 & -0.004 \\
\hline Rate & $(0.027)$ & $(0.320)$ & $(0.004)$ \\
\hline R-squared & 0.56 & 0.59 & 0.63 \\
\hline F-statistic & 35.63 & 34.29 & 121.37 \\
\hline
\end{tabular}

Notes: Robust standard errors in parentheses; ${ }^{* * *} p<0.01,{ }^{* *} p<0.05,{ }^{*} p<0.1$. Second-stage results in Table 2. Panel B includes employer tenure squared, potential experience squared and cubed, and education squared 
Table 12 First-stage regressions: returns to employer, occupation, industry, and sector tenure

\begin{tabular}{|c|c|c|c|c|c|}
\hline \multicolumn{6}{|l|}{ Panel A. Linear model } \\
\hline \multirow{2}{*}{ Endogenous variable } & (1) & (2) & (3) & (4) & (5) \\
\hline & Employer & Occupation & Industry & Sector & Employer tenure $>1$ \\
\hline \multirow[t]{2}{*}{ Employer tenure } & $1.005^{* * *}$ & 0.095 & -0.050 & $-0.208^{* * *}$ & $0.034^{* * *}$ \\
\hline & $(0.055)$ & $(0.062)$ & $(0.061)$ & $(0.062)$ & $(0.008)$ \\
\hline \multirow[t]{2}{*}{ Occupation tenure } & $0.142^{* * *}$ & $0.928^{* * *}$ & 0.054 & $0.084^{* *}$ & $0.012^{* *}$ \\
\hline & $(0.037)$ & $(0.038)$ & $(0.039)$ & $(0.039)$ & $(0.005)$ \\
\hline \multirow[t]{2}{*}{ Industry tenure } & $-0.072^{*}$ & -0.008 & $0.953^{* * *}$ & 0.031 & -0.011 \\
\hline & $(0.044)$ & $(0.048)$ & $(0.055)$ & $(0.051)$ & $(0.008)$ \\
\hline \multirow[t]{2}{*}{ Potential experience } & $0.024^{* * *}$ & 0.008 & $0.028^{* * *}$ & $0.021^{* * *}$ & $0.002^{*}$ \\
\hline & $(0.008)$ & $(0.006)$ & $(0.008)$ & $(0.008)$ & $(0.001)$ \\
\hline \multirow[t]{2}{*}{ Sector tenure } & $-0.153^{* * *}$ & $-0.076^{*}$ & $-0.074^{*}$ & $0.929^{* * *}$ & $-0.016^{* *}$ \\
\hline & $(0.042)$ & $(0.045)$ & $(0.044)$ & $(0.049)$ & $(0.006)$ \\
\hline \multirow[t]{2}{*}{ Employer tenure $>1$} & $0.363^{* *}$ & $0.320^{* *}$ & $0.262^{*}$ & $0.704^{* * *}$ & $1.002^{* * *}$ \\
\hline & $(0.141)$ & $(0.142)$ & $(0.149)$ & $(0.150)$ & $(0.015)$ \\
\hline \multirow[t]{2}{*}{ Informal } & $-0.947^{* * *}$ & $-0.441^{* * *}$ & $-0.999 * * *$ & $-0.460^{* * *}$ & $-0.098^{* * *}$ \\
\hline & $(0.110)$ & $(0.106)$ & $(0.117)$ & $(0.113)$ & $(0.016)$ \\
\hline \multirow[t]{2}{*}{ Married } & $0.915^{* * *}$ & $0.711^{* * *}$ & $1.102^{* * *}$ & $1.044^{* * *}$ & $0.102^{* * *}$ \\
\hline & $(0.129)$ & $(0.127)$ & $(0.138)$ & $(0.134)$ & $(0.018)$ \\
\hline \multirow[t]{2}{*}{ Education } & 0.020 & -0.014 & 0.025 & -0.005 & 0.002 \\
\hline & $(0.022)$ & $(0.021)$ & $(0.023)$ & $(0.022)$ & $(0.003)$ \\
\hline Province unemployment & -0.012 & 0.052 & 0.013 & 0.057 & -0.006 \\
\hline Rate & $(0.046)$ & $(0.046)$ & $(0.049)$ & $(0.049)$ & $(0.007)$ \\
\hline R-squared & 0.57 & 0.57 & 0.65 & 0.57 & 0.64 \\
\hline F-statistic & 30.57 & 24.15 & 50.95 & 30.42 & 124.00 \\
\hline
\end{tabular}


Table 12 First-stage regressions: returns to employer, occupation, industry, and sector tenure (Continued)

\begin{tabular}{|c|c|c|c|c|c|c|c|c|c|c|c|c|}
\hline \multicolumn{13}{|c|}{ Panel B. Non-linear model } \\
\hline \multirow[b]{2}{*}{$\begin{array}{l}\text { Endogenous } \\
\text { variable }\end{array}$} & (1) & (2) & (3) & (4) & (5) & (6) & (7) & (8) & (9) & (10) & (11) & (12) \\
\hline & Employer & $\begin{array}{l}\text { Employer } \\
\text { tenure }^{2}\end{array}$ & $\begin{array}{l}\text { Occupation } \\
\text { tenure }\end{array}$ & $\begin{array}{l}\text { Occupation } \\
\text { tenure }\end{array}$ & $\begin{array}{l}\text { Occupation } \\
\text { tenure }^{3}\end{array}$ & $\begin{array}{l}\text { Industry } \\
\text { tenure }\end{array}$ & $\begin{array}{l}\text { Industry } \\
\text { tenure }\end{array}$ & $\begin{array}{l}\text { Industry } \\
\text { tenure }\end{array}$ & $\begin{array}{l}\text { Sector } \\
\text { tenure }\end{array}$ & $\begin{array}{l}\text { Sector } \\
\text { tenure }^{2}\end{array}$ & $\begin{array}{l}\text { Sector } \\
\text { tenure }^{3}\end{array}$ & $\begin{array}{l}\text { Employer } \\
\text { tenure }>1\end{array}$ \\
\hline \multirow[t]{2}{*}{ Employer tenure } & $0.779^{* * *}$ & -2.461 & 0.163 & 2.542 & $36.362^{*}$ & $0.325^{* *}$ & $5.038^{* *}$ & $75.129^{*}$ & $0.330^{* *}$ & $5.464^{* *}$ & $86.490^{* *}$ & 0.031 \\
\hline & $(0.150)$ & $(1.962)$ & $(0.146)$ & $(1.698)$ & $(21.452)$ & $(0.161)$ & $(2.530)$ & $(39.717)$ & $(0.164)$ & $(2.526)$ & (39.355) & $(0.021)$ \\
\hline \multirow[t]{2}{*}{ Employer tenure $^{2}$} & 0.017 & $1.124^{* * *}$ & -0.003 & -0.085 & -1.458 & $-0.026^{* *}$ & $-0.402^{* *}$ & $-5.994^{* *}$ & $-0.034^{* * *}$ & $-0.498^{* *}$ & $-7.243^{* *}$ & 0.000 \\
\hline & $(0.011)$ & $(0.155)$ & $(0.010)$ & $(0.128)$ & $(1.701)$ & $(0.011)$ & $(0.189)$ & $(3.010)$ & $(0.012)$ & $(0.196)$ & $(3.097)$ & $(0.001)$ \\
\hline \multirow[t]{2}{*}{ Occupation tenure } & 0.049 & -1.508 & $0.870^{* * *}$ & 2.308 & $70.284^{* *}$ & 0.091 & 0.408 & 5.892 & 0.073 & -0.841 & -24.604 & $0.074^{* * *}$ \\
\hline & $(0.234)$ & (3.391) & $(0.202)$ & $(2.430)$ & $(30.854)$ & $(0.227)$ & (3.384) & $(50.875)$ & $(0.245)$ & $(3.607)$ & $(53.279)$ & $(0.026)$ \\
\hline \multirow[t]{2}{*}{ Occupation tenure ${ }^{2}$} & 0.006 & 0.359 & -0.014 & 0.103 & $-17.233^{* * *}$ & -0.013 & -0.135 & -2.690 & -0.002 & 0.218 & 4.747 & $-0.009^{* *}$ \\
\hline & $(0.040)$ & $(0.598)$ & $(0.034)$ & $(0.428)$ & $(5.629)$ & $(0.038)$ & $(0.595)$ & $(9.158)$ & $(0.042)$ & $(0.638)$ & $(9.583)$ & $(0.004)$ \\
\hline \multirow[t]{2}{*}{ Occupation tenure ${ }^{3}$} & 0.000 & -0.008 & 0.002 & $0.048^{* *}$ & $1.803^{* * *}$ & 0.001 & 0.013 & 0.247 & 0.000 & -0.005 & -0.122 & $0.000^{* *}$ \\
\hline & $(0.002)$ & $(0.028)$ & $(0.002)$ & $(0.020)$ & $(0.280)$ & $(0.002)$ & $(0.028)$ & $(0.436)$ & $(0.002)$ & $(0.030)$ & $(0.460)$ & $(0.000)$ \\
\hline \multirow[t]{2}{*}{ Industry tenure } & 0.093 & 4.078 & 0.041 & 0.951 & 16.320 & 0.187 & -4.832 & -5.883 & $0.723^{* * *}$ & $10.064^{* *}$ & $134.044^{* *}$ & $-0.105^{* * *}$ \\
\hline & $(0.228)$ & (3.323) & $(0.185)$ & $(1.922)$ & $(22.267)$ & $(0.238)$ & $(3.580)$ & $(54.697)$ & $(0.277)$ & $(4.119)$ & $(62.132)$ & $(0.032)$ \\
\hline \multirow[t]{2}{*}{ Industry tenure ${ }^{2}$} & -0.016 & -0.562 & -0.023 & -0.339 & -4.976 & $0.071^{*}$ & $1.190^{* *}$ & -3.408 & $-0.114^{* * *}$ & $-1.570^{* *}$ & $-20.905^{* *}$ & $0.014^{* * *}$ \\
\hline & $(0.034)$ & $(0.516)$ & $(0.026)$ & $(0.278)$ & (3.364) & $(0.037)$ & $(0.598)$ & $(9.539)$ & $(0.042)$ & $(0.663)$ & $(10.277)$ & $(0.004)$ \\
\hline \multirow[t]{2}{*}{ Industry tenure ${ }^{3}$} & 0.000 & 0.017 & 0.001 & $0.021^{*}$ & $0.297^{*}$ & -0.001 & 0.008 & $1.265^{* * *}$ & $0.005^{* *}$ & $0.066^{* *}$ & $0.889^{*}$ & $-0.001^{* * *}$ \\
\hline & $(0.001)$ & $(0.022)$ & $(0.001)$ & $(0.012)$ & $(0.157)$ & $(0.002)$ & $(0.028)$ & $(0.451)$ & $(0.002)$ & $(0.030)$ & $(0.481)$ & $(0.000)$ \\
\hline \multirow[t]{2}{*}{ Potential experience } & $0.184^{* * *}$ & $1.918^{* * *}$ & $0.095^{* * *}$ & $0.881^{* * *}$ & $8.015^{* * *}$ & $0.250^{* * *}$ & $2.838^{* * *}$ & $32.187^{* * *}$ & $0.206^{* * *}$ & $2.127^{* * *}$ & $21.902^{* * *}$ & $0.021^{* * *}$ \\
\hline & $(0.027)$ & $(0.310)$ & $(0.027)$ & $(0.276)$ & $(3.022)$ & $(0.029)$ & $(0.355)$ & $(4.484)$ & $(0.028)$ & $(0.347)$ & $(4.517)$ & $(0.004)$ \\
\hline \multirow[t]{2}{*}{ Potential experience ${ }^{2}$} & $-0.006^{* * *}$ & $-0.062^{* * *}$ & $-0.003^{* * *}$ & $-0.028^{* *}$ & $-0.260^{* *}$ & $-0.008^{* * *}$ & $-0.093^{* * *}$ & $-1.055^{* * *}$ & $-0.007^{* * *}$ & $-0.065^{* * *}$ & $-0.588^{* *}$ & $-0.001^{* * *}$ \\
\hline & $(0.001)$ & $(0.014)$ & $(0.001)$ & $(0.012)$ & $(0.131)$ & $(0.001)$ & $(0.016)$ & $(0.203)$ & $(0.001)$ & $(0.017)$ & $(0.229)$ & $(0.000)$ \\
\hline Potential experience ${ }^{3}$ & $0.000^{* * *}$ & $0.001^{* * *}$ & $0.000^{* *}$ & $0.000^{*}$ & 0.002 & $0.000^{* * *}$ & $0.001^{* * *}$ & $0.010^{* * *}$ & $0.000^{* * *}$ & $0.001^{* * *}$ & $0.005^{*}$ & $0.000^{* * *}$ \\
\hline
\end{tabular}


Table 12 First-stage regressions: returns to employer, occupation, industry, and sector tenure (Continued)

\begin{tabular}{|c|c|c|c|c|c|c|c|c|c|c|c|c|}
\hline & $(0.000)$ & $(0.000)$ & $(0.000)$ & $(0.000)$ & $(0.001)$ & $(0.000)$ & $(0.000)$ & $(0.002)$ & $(0.000)$ & $(0.000)$ & $(0.003)$ & $(0.000)$ \\
\hline \multirow[t]{2}{*}{ Sector tenure } & $0.469^{* *}$ & $5.947^{* *}$ & 0.263 & 2.191 & 17.103 & $0.403^{* *}$ & $4.819^{*}$ & 59.537 & 0.081 & $-7.253^{* *}$ & -45.638 & $0.066^{* *}$ \\
\hline & $(0.192)$ & $(2.441)$ & $(0.176)$ & $(1.799)$ & (20.696) & $(0.202)$ & $(2.782)$ & $(41.180)$ & $(0.241)$ & (3.543) & $(52.817)$ & $(0.034)$ \\
\hline \multirow[t]{2}{*}{ Sector tenure ${ }^{2}$} & $-0.077^{* * *}$ & $-0.876^{* *}$ & -0.035 & -0.228 & -1.018 & $-0.061^{* *}$ & $-0.723^{*}$ & -9.301 & $0.099^{* *}$ & $1.635^{* * *}$ & 2.318 & $-0.013^{* * *}$ \\
\hline & $(0.027)$ & $(0.371)$ & $(0.025)$ & $(0.270)$ & (3.346) & $(0.028)$ & $(0.419)$ & $(6.432)$ & $(0.039)$ & $(0.614)$ & $(9.523)$ & $(0.004)$ \\
\hline \multirow[t]{2}{*}{ Sector tenure ${ }^{3}$} & $0.002^{* *}$ & 0.025 & 0.001 & 0.001 & -0.050 & 0.002 & 0.021 & 0.287 & $-0.003^{*}$ & -0.021 & $0.899^{*}$ & $0.001^{* * *}$ \\
\hline & $(0.001)$ & $(0.016)$ & $(0.001)$ & $(0.012)$ & $(0.153)$ & $(0.001)$ & $(0.018)$ & $(0.288)$ & $(0.002)$ & $(0.030)$ & $(0.482)$ & $(0.000)$ \\
\hline \multirow[t]{2}{*}{ Employer tenure $>1$} & -0.116 & -1.911 & 0.006 & -2.425 & $-52.885^{* *}$ & 0.083 & -2.031 & -68.234 & 0.212 & -0.444 & -46.268 & $0.983^{* * *}$ \\
\hline & $(0.211)$ & $(2.542)$ & $(0.208)$ & $(2.203)$ & (24.931) & $(0.220)$ & $(2.969)$ & $(42.231)$ & $(0.231)$ & (3.084) & $(43.360)$ & $(0.026)$ \\
\hline \multirow[t]{2}{*}{ Informal } & $-0.847^{* * *}$ & $-9.740^{* * *}$ & $-0.366^{* * *}$ & $-4.022^{* * *}$ & $-45.119^{* * *}$ & $-0.860^{* * *}$ & $10.602^{* * *}$ & $24.954^{* * *}$ & $-0.342^{* * *}$ & $-4.870^{* * *}$ & $61.468^{* * *}$ & $-0.089^{* * *}$ \\
\hline & $(0.109)$ & (1.291) & $(0.106)$ & (1.104) & $(12.213)$ & $(0.112)$ & (1.364) & (17.491) & $(0.112)$ & $(1.352)$ & $(17.286)$ & $(0.016)$ \\
\hline \multirow[t]{2}{*}{ Married } & $0.595^{* * *}$ & $7.235^{* * *}$ & $0.516^{* * *}$ & $5.824^{* * *}$ & $66.082^{* * *}$ & $0.611^{* * *}$ & $7.688^{* * *}$ & $98.061^{* * *}$ & $0.643^{* * *}$ & $8.460^{* * * 1}$ & $10.001^{* * *}$ & $0.062^{* * *}$ \\
\hline & $(0.130)$ & $(1.552)$ & $(0.140)$ & $(1.526)$ & (17.754) & $(0.138)$ & (1.716) & (22.758) & $(0.136)$ & (1.649) & (21.135) & $(0.020)$ \\
\hline \multirow[t]{2}{*}{ Education } & $0.235^{* * *}$ & $4.179^{* * *}$ & 0.116 & 1.210 & 9.337 & $0.203^{* *}$ & $3.683^{* * *}$ & $52.923^{* * *}$ & $0.263^{* * *}$ & $4.385^{* * *}$ & $60.189^{* * *}$ & -0.022 \\
\hline & $(0.090)$ & $(1.073)$ & (0.089) & $(0.945)$ & $(10.543)$ & $(0.092)$ & (1.119) & (14.314) & $(0.088)$ & $(1.094)$ & $(14.256)$ & $(0.013)$ \\
\hline \multirow[t]{2}{*}{ Education ${ }^{2}$} & $-0.010^{* *}$ & $-0.192^{* * *}$ & -0.006 & -0.072 & -0.647 & $-0.008^{*}$ & $-0.165^{* * *}$ & $-2.441^{* * *}$ & $-0.013^{* * *}$ & $-0.216^{* * *}$ & $-2.967^{* * *}$ & $0.001^{*}$ \\
\hline & $(0.004)$ & $(0.049)$ & $(0.004)$ & $(0.045)$ & $(0.495)$ & $(0.004)$ & $(0.052)$ & $(0.655)$ & $(0.004)$ & $(0.050)$ & $(0.642)$ & $(0.001)$ \\
\hline Province unemployment & -0.016 & -0.089 & 0.031 & 0.299 & 3.228 & -0.006 & 0.043 & 0.940 & 0.070 & 0.823 & 10.333 & -0.007 \\
\hline Rate & $(0.045)$ & $(0.549)$ & $(0.044)$ & $(0.481)$ & $(5.510)$ & $(0.047)$ & $(0.593)$ & $(7.877)$ & $(0.048)$ & $(0.592)$ & $(7.823)$ & $(0.007)$ \\
\hline R-squared & 0.58 & 0.62 & 0.58 & 0.66 & 0.73 & 0.67 & 0.72 & 0.75 & 0.60 & 0.63 & 0.67 & 0.65 \\
\hline F-statistic & 32.89 & 25.47 & 29.97 & 28.64 & 25.30 & 66.91 & 59.82 & 50.68 & 41.25 & 29.75 & 21.46 & 103.22 \\
\hline
\end{tabular}

Notes: Robust standard errors in parentheses; ${ }^{* * *} p<0.01,{ }^{* *} p<0.05,{ }^{*} p<0.1$. Second-stage results in Table 3. Panel B includes employer tenure squared, potential experience squared and cubed, sector tenure squared and cubed, and education squared 
Table 13 First-stage regressions: returns to tenure by sector

\begin{tabular}{|c|c|c|c|c|c|c|}
\hline & (1) & (2) & (3) & (4) & (5) & (6) \\
\hline & Employer tenure & Occupation tenure & Industry tenure & Sector tenure & Sector tenure $\times$ informal & Employer tenure $>1$ \\
\hline \multirow[t]{2}{*}{ Employer tenure } & $1.026^{* * *}$ & 0.069 & -0.050 & $-0.216^{* * *}$ & $-0.122^{* *}$ & $0.036^{* * *}$ \\
\hline & $(0.057)$ & $(0.067)$ & $(0.063)$ & $(0.062)$ & $(0.052)$ & $(0.008)$ \\
\hline \multirow[t]{2}{*}{ Occupation tenure } & $0.136^{* * *}$ & $0.935^{* * *}$ & 0.054 & $0.086^{* *}$ & 0.037 & $0.011^{* *}$ \\
\hline & $(0.037)$ & $(0.038)$ & $(0.039)$ & $(0.040)$ & $(0.029)$ & $(0.005)$ \\
\hline \multirow[t]{2}{*}{ Industry tenure } & -0.067 & -0.015 & $0.953^{* * *}$ & 0.029 & 0.020 & -0.010 \\
\hline & $(0.044)$ & $(0.048)$ & $(0.055)$ & $(0.051)$ & $(0.040)$ & $(0.008)$ \\
\hline \multirow[t]{2}{*}{ Potential experience } & $0.024^{* * *}$ & 0.008 & $0.028^{* * *}$ & $0.021^{* * *}$ & $0.015^{* *}$ & $0.002^{*}$ \\
\hline & $(0.008)$ & $(0.006)$ & $(0.008)$ & $(0.008)$ & $(0.007)$ & $(0.001)$ \\
\hline \multirow[t]{2}{*}{ Sector tenure } & $-0.205^{* * *}$ & -0.014 & -0.073 & $0.949^{* * *}$ & 0.061 & $-0.021^{* * *}$ \\
\hline & $(0.059)$ & $(0.060)$ & $(0.056)$ & $(0.061)$ & $(0.039)$ & $(0.007)$ \\
\hline \multirow[t]{2}{*}{ Informal $\times$ Sector tenure } & 0.070 & $-0.083^{*}$ & -0.001 & -0.027 & $0.805^{* * *}$ & 0.008 \\
\hline & $(0.051)$ & $(0.049)$ & $(0.047)$ & $(0.052)$ & $(0.038)$ & $(0.005)$ \\
\hline \multirow[t]{2}{*}{ Informal } & $-0.930^{* * *}$ & $-0.461^{* * *}$ & $-0.999^{* * *}$ & $-0.466^{* * *}$ & $3.498^{* * *}$ & $-0.097^{* * *}$ \\
\hline & $(0.112)$ & $(0.107)$ & $(0.118)$ & $(0.116)$ & $(0.075)$ & $(0.016)$ \\
\hline \multirow[t]{2}{*}{ Employer tenure $>1$} & $0.330^{* *}$ & $0.358^{* *}$ & $0.263^{*}$ & $0.716^{* * *}$ & $0.367^{* * *}$ & $0.999^{* * *}$ \\
\hline & $(0.145)$ & $(0.144)$ & $(0.151)$ & $(0.151)$ & $(0.116)$ & $(0.016)$ \\
\hline \multirow[t]{2}{*}{ Married } & $0.914^{* * *}$ & $0.712^{* * *}$ & $1.102^{* * *}$ & $1.045^{* * *}$ & $0.450^{* * *}$ & $0.102^{* * *}$ \\
\hline & $(0.129)$ & $(0.127)$ & $(0.138)$ & $(0.134)$ & $(0.107)$ & $(0.018)$ \\
\hline \multirow[t]{2}{*}{ Education } & 0.020 & -0.015 & 0.025 & -0.005 & $-0.043^{* *}$ & 0.002 \\
\hline & $(0.022)$ & $(0.021)$ & $(0.023)$ & $(0.022)$ & $(0.019)$ & $(0.003)$ \\
\hline Province unemployment & -0.014 & 0.053 & 0.013 & 0.057 & 0.027 & -0.006 \\
\hline
\end{tabular}


Table 13 First-stage regressions: returns to tenure by sector (Continued)

\begin{tabular}{|c|c|c|c|c|c|c|}
\hline Rate & $(0.046)$ & $(0.046)$ & (0.049) & (0.049) & $(0.036)$ & $(0.007)$ \\
\hline R-squared & 0.573 & 0.572 & 0.648 & 0.637 & 0.574 & 0.713 \\
\hline F-statistic & 29.77 & 24.35 & 50.07 & 19.6 & 30.31 & 64.94 \\
\hline
\end{tabular}


Table 14 First-stage regressions: informal: self-employed and salaried informal in same category

\begin{tabular}{|c|c|c|c|c|c|c|}
\hline & (1) & (2) & (3) & (4) & (5) & (6) \\
\hline & Employer tenure & Occupation tenure & Industry tenure & Sector tenure & Sector tenure $\times$ informal & Employer tenure $>1$ \\
\hline \multirow[t]{2}{*}{ Employer tenure } & $1.011^{* * *}$ & 0.085 & -0.033 & $-0.190^{* * *}$ & $-0.092^{*}$ & $0.037^{* * *}$ \\
\hline & $(0.058)$ & $(0.068)$ & $(0.063)$ & $(0.062)$ & $(0.051)$ & $(0.008)$ \\
\hline \multirow[t]{2}{*}{ Occupation tenure } & $0.126^{* * *}$ & $0.909^{* * *}$ & 0.046 & 0.050 & 0.007 & $0.010^{* *}$ \\
\hline & $(0.038)$ & $(0.039)$ & $(0.040)$ & $(0.041)$ & $(0.030)$ & $(0.005)$ \\
\hline \multirow[t]{2}{*}{ Industry tenure } & $-0.089^{*}$ & -0.007 & $0.917^{* * *}$ & -0.001 & -0.003 & $-0.017^{* *}$ \\
\hline & $(0.047)$ & $(0.050)$ & $(0.057)$ & $(0.054)$ & $(0.041)$ & $(0.008)$ \\
\hline \multirow[t]{2}{*}{ Potential experience } & $0.032^{* * *}$ & 0.011 & $0.037^{* * *}$ & $0.027^{* * *}$ & $0.019^{* *}$ & $0.002^{* *}$ \\
\hline & $(0.008)$ & $(0.007)$ & $(0.008)$ & $(0.008)$ & $(0.008)$ & $(0.001)$ \\
\hline \multirow[t]{2}{*}{ Sector tenure } & $-0.179 * * *$ & -0.040 & -0.071 & $0.968^{* * *}$ & 0.056 & $-0.018^{* * *}$ \\
\hline & $(0.059)$ & $(0.060)$ & $(0.056)$ & $(0.061)$ & $(0.040)$ & $(0.007)$ \\
\hline \multirow[t]{2}{*}{ Informal $\times$ sector tenure } & 0.076 & $-0.087^{*}$ & -0.017 & -0.041 & $0.792^{* * *}$ & 0.007 \\
\hline & $(0.051)$ & $(0.049)$ & $(0.047)$ & $(0.051)$ & $(0.038)$ & $(0.005)$ \\
\hline \multirow[t]{2}{*}{ Informal } & $-0.863^{* * *}$ & $-0.415^{* * *}$ & $-0.930^{* * *}$ & $-0.209^{*}$ & $3.747^{* * *}$ & $-0.084^{* * *}$ \\
\hline & $(0.115)$ & $(0.111)$ & $(0.120)$ & $(0.119)$ & $(0.080)$ & $(0.017)$ \\
\hline \multirow[t]{2}{*}{ Employer 10} & $0.320^{* *}$ & $0.375^{* *}$ & $0.257^{*}$ & $0.726^{* * *}$ & $0.379^{* * *}$ & $1.001^{* * *}$ \\
\hline & $(0.148)$ & $(0.147)$ & $(0.153)$ & $(0.154)$ & $(0.118)$ & $(0.016)$ \\
\hline \multirow[t]{2}{*}{ Married } & $0.978^{* * *}$ & $0.785^{* * *}$ & $1.204^{* * *}$ & $1.283^{* * *}$ & $0.681^{* * *}$ & $0.112^{* * *}$ \\
\hline & $(0.135)$ & $(0.132)$ & $(0.144)$ & $(0.140)$ & $(0.112)$ & (0.019) \\
\hline \multirow[t]{2}{*}{ Education } & 0.017 & 0.004 & 0.033 & -0.007 & $-0.045^{* *}$ & 0.002 \\
\hline & $(0.024)$ & $(0.022)$ & $(0.025)$ & $(0.025)$ & $(0.021)$ & $(0.003)$ \\
\hline
\end{tabular}


Table 14 First-stage regressions: informal: self-employed and salaried informal in same category (Continued)

\begin{tabular}{|c|c|c|c|c|c|c|}
\hline Province unemployment & -0.009 & 0.069 & 0.016 & 0.053 & 0.025 & -0.003 \\
\hline Rate & $(0.048)$ & $(0.047)$ & $(0.051)$ & $(0.051)$ & $(0.038)$ & $(0.007)$ \\
\hline R-squared & 0.5831 & 0.578 & 0.66 & 0.596 & 0.7347 & 0.649 \\
\hline F-statistic & 29.48 & 47.41 & 56.19 & 83.18 & 510 & 120.51 \\
\hline
\end{tabular}

Notes: Robust standard errors in parentheses; ${ }^{* * *} p<0.01,{ }^{* *} p<0.05,{ }^{*} p<0.1$. Second-stage results in Table 8 
Table 15 First-stage regressions: informal: not using information on medical benefits

\begin{tabular}{|c|c|c|c|c|c|c|}
\hline & (1) & (2) & (3) & (4) & (5) & (6) \\
\hline & Employer tenure & Occupation tenure & Industry tenure & Sector tenure & Sector tenure $\times$ informal & Employer tenure $>1$ \\
\hline \multirow[t]{2}{*}{ Employer tenure } & $0.947^{* * *}$ & 0.077 & -0.087 & $-0.153^{* *}$ & -0.072 & $0.029 * * *$ \\
\hline & $(0.061)$ & $(0.071)$ & $(0.068)$ & $(0.072)$ & $(0.060)$ & $(0.009)$ \\
\hline \multirow[t]{2}{*}{ Occupation tenure } & $0.150^{* * *}$ & $0.910^{* * *}$ & $0.067^{*}$ & $0.104^{* *}$ & 0.043 & $0.013^{* * *}$ \\
\hline & $(0.038)$ & $(0.038)$ & $(0.039)$ & $(0.040)$ & $(0.030)$ & $(0.005)$ \\
\hline \multirow[t]{2}{*}{ Industry tenure } & $-0.079^{*}$ & -0.040 & $0.940^{* * *}$ & -0.042 & -0.032 & -0.009 \\
\hline & $(0.044)$ & $(0.051)$ & $(0.056)$ & $(0.053)$ & $(0.040)$ & $(0.008)$ \\
\hline \multirow[t]{2}{*}{ Potential experience } & $0.020^{* *}$ & 0.010 & $0.027^{* * *}$ & $0.020^{* * *}$ & $0.015^{* *}$ & 0.001 \\
\hline & $(0.008)$ & $(0.007)$ & $(0.008)$ & $(0.008)$ & $(0.007)$ & $(0.001)$ \\
\hline \multirow[t]{2}{*}{ Sector tenure } & -0.081 & -0.016 & -0.012 & $0.957^{* * *}$ & 0.041 & -0.013 \\
\hline & $(0.059)$ & $(0.069)$ & $(0.065)$ & $(0.070)$ & $(0.050)$ & $(0.009)$ \\
\hline \multirow[t]{2}{*}{ Informal $\times$ sector tenure } & 0.021 & 0.003 & -0.028 & 0.001 & $0.838^{* * *}$ & 0.002 \\
\hline & $(0.050)$ & $(0.049)$ & $(0.046)$ & $(0.051)$ & $(0.037)$ & $(0.005)$ \\
\hline \multirow[t]{2}{*}{ Informal } & $-0.861^{* * *}$ & $-0.316^{* * *}$ & $-0.853^{* * *}$ & $-0.405^{* * *}$ & $3.705^{* * *}$ & $-0.087^{* * *}$ \\
\hline & $(0.118)$ & $(0.113)$ & $(0.124)$ & $(0.124)$ & $(0.081)$ & $(0.017)$ \\
\hline \multirow[t]{2}{*}{ Employer tenure $>1$} & $0.333^{* *}$ & $0.346^{* *}$ & $0.301^{*}$ & $0.488^{* * *}$ & $0.233^{*}$ & $1.001^{* * *}$ \\
\hline & $(0.149)$ & $(0.148)$ & $(0.156)$ & $(0.155)$ & $(0.120)$ & $(0.016)$ \\
\hline \multirow[t]{2}{*}{ Married } & $0.901^{* * *}$ & $0.682^{* * *}$ & $1.033^{* * *}$ & $1.083^{* * *}$ & $0.482^{* * *}$ & $0.104^{* * *}$ \\
\hline & $(0.134)$ & $(0.129)$ & $(0.143)$ & $(0.140)$ & $(0.111)$ & $(0.019)$ \\
\hline \multirow[t]{2}{*}{ Education } & 0.011 & -0.009 & 0.023 & 0.026 & -0.021 & -0.000 \\
\hline & $(0.023)$ & $(0.021)$ & $(0.023)$ & $(0.023)$ & $(0.019)$ & $(0.003)$ \\
\hline
\end{tabular}


Table 15 First-stage regressions: informal: not using information on medical benefits (Continued)

\begin{tabular}{|c|c|c|c|c|c|c|}
\hline Province unemployment & -0.028 & 0.063 & 0.012 & 0.037 & 0.038 & -0.006 \\
\hline Rate & $(0.047)$ & $(0.048)$ & $(0.051)$ & $(0.051)$ & $(0.037)$ & $(0.007)$ \\
\hline R-squared & 0.56 & 0.56 & 0.64 & 0.60 & 0.73 & 0.64 \\
\hline F-statistic & 28.11 & 22.73 & 47.06 & 32.64 & 70.89 & 119.58 \\
\hline
\end{tabular}

Notes: Robust standard errors in parentheses; ${ }^{* * *} p<0.01,{ }^{* *} p<0.05,{ }^{*} p<0.1$. Second-stage results in Table 8 
Table 16 First-stage regressions: informal: all self-employed and small firms

\begin{tabular}{|c|c|c|c|c|c|c|}
\hline & (1) & (2) & (3) & (4) & (5) & (6) \\
\hline & Employer tenure & Occupation tenure & Industry tenure & Sector tenure & Sector tenure $\times$ informal & Employer tenure $>1$ \\
\hline \multirow[t]{2}{*}{ Employer tenure } & $1.030^{* * *}$ & 0.073 & -0.056 & $-0.197^{* * *}$ & $-0.111^{* *}$ & $0.036^{* * *}$ \\
\hline & $(0.054)$ & $(0.064)$ & $(0.061)$ & $(0.063)$ & $(0.050)$ & $(0.008)$ \\
\hline \multirow[t]{2}{*}{ Occupation tenure } & $0.152^{* * *}$ & $0.950^{* * *}$ & $0.068^{*}$ & $0.086^{* *}$ & 0.037 & $0.012^{* *}$ \\
\hline & $(0.037)$ & $(0.039)$ & $(0.038)$ & $(0.040)$ & $(0.029)$ & $(0.005)$ \\
\hline \multirow[t]{2}{*}{ Industry tenure } & $-0.082^{*}$ & -0.033 & $0.960^{* * *}$ & -0.002 & -0.027 & $-0.014^{*}$ \\
\hline & $(0.043)$ & $(0.048)$ & $(0.055)$ & $(0.051)$ & $(0.040)$ & $(0.008)$ \\
\hline \multirow[t]{2}{*}{ Potential experience } & $-0.197^{* * *}$ & -0.004 & -0.073 & $0.963^{* * *}$ & $0.082^{* *}$ & $-0.018^{* * *}$ \\
\hline & $(0.055)$ & $(0.059)$ & $(0.054)$ & $(0.061)$ & $(0.035)$ & $(0.006)$ \\
\hline \multirow[t]{2}{*}{ Sector tenure } & 0.053 & $-0.084^{*}$ & -0.031 & -0.019 & $0.823^{* * *}$ & 0.006 \\
\hline & $(0.051)$ & $(0.050)$ & $(0.048)$ & $(0.055)$ & $(0.039)$ & $(0.005)$ \\
\hline \multirow[t]{2}{*}{ Informal $\times$ sector tenure } & $0.023^{* * *}$ & 0.009 & $0.027^{* * *}$ & $0.013^{*}$ & 0.008 & 0.002 \\
\hline & $(0.008)$ & $(0.006)$ & $(0.008)$ & $(0.008)$ & $(0.007)$ & $(0.001)$ \\
\hline \multirow[t]{2}{*}{ Informal } & $-0.948^{* * *}$ & $-0.465^{* * *}$ & $-0.991^{* * *}$ & $-0.465^{* * *}$ & $3.383^{* * *}$ & $-0.097^{* * *}$ \\
\hline & $(0.112)$ & $(0.108)$ & $(0.118)$ & $(0.117)$ & $(0.074)$ & $(0.016)$ \\
\hline \multirow[t]{2}{*}{ Employer tenure $>1$} & $0.330^{* *}$ & $0.360^{* *}$ & $0.269^{*}$ & $0.712^{* * *}$ & $0.372^{* * *}$ & $1.001^{* * *}$ \\
\hline & $(0.144)$ & $(0.145)$ & $(0.151)$ & $(0.151)$ & $(0.117)$ & $(0.016)$ \\
\hline \multirow[t]{2}{*}{ Married } & $0.953^{* * *}$ & $0.670^{* * *}$ & $1.097^{* * *}$ & $1.096^{* * *}$ & $0.518^{* * *}$ & $0.107^{* * *}$ \\
\hline & $(0.130)$ & $(0.130)$ & $(0.140)$ & $(0.137)$ & $(0.109)$ & $(0.018)$ \\
\hline \multirow[t]{2}{*}{ Education } & 0.020 & -0.011 & 0.026 & -0.009 & $-0.054^{* * *}$ & 0.001 \\
\hline & $(0.022)$ & $(0.021)$ & $(0.023)$ & $(0.022)$ & (0.019) & $(0.003)$ \\
\hline
\end{tabular}


Table 16 First-stage regressions: informal: all self-employed and small firms (Continued)

\begin{tabular}{|c|c|c|c|c|c|c|}
\hline Province unemployment & -0.020 & 0.050 & -0.000 & 0.076 & $0.060^{*}$ & -0.006 \\
\hline Rate & $(0.046)$ & $(0.047)$ & $(0.049)$ & $(0.049)$ & $(0.036)$ & $(0.007)$ \\
\hline R-squared & 0.58 & 0.57 & 0.65 & 0.57 & 0.72 & 0.64 \\
\hline F-statistic & 31.51 & 24.76 & 53.44 & 30.23 & 67.82 & 18.01 \\
\hline
\end{tabular}

Notes: Robust standard errors in parentheses; ${ }^{* * *} p<0.01,{ }^{* *} p<0.05,{ }^{*} p<0.1$. Second-stage results in Table 8 
Table 17 First-stage regressions: informal: based on medical benefits only

\begin{tabular}{|c|c|c|c|c|c|c|}
\hline & (1) & (2) & (3) & (4) & (5) & (6) \\
\hline & Employer tenure & Occupation tenure & Industry tenure & Sector tenure & Sector tenure $\times$ informal & Employer tenure $>1$ \\
\hline \multirow[t]{2}{*}{ Employer tenure } & $1.337^{* * *}$ & 0.114 & 0.000 & $-0.152^{* *}$ & $-0.108^{* *}$ & $0.075^{* * *}$ \\
\hline & $(0.065)$ & $(0.096)$ & $(0.072)$ & $(0.071)$ & $(0.055)$ & $(0.010)$ \\
\hline \multirow[t]{2}{*}{ Occupation tenure } & 0.038 & $0.955^{* * *}$ & -0.042 & 0.012 & 0.005 & -0.005 \\
\hline & $(0.042)$ & $(0.045)$ & $(0.041)$ & $(0.040)$ & $(0.032)$ & $(0.005)$ \\
\hline \multirow[t]{2}{*}{ Industry tenure } & $-0.178^{* * *}$ & -0.038 & $1.063^{* * *}$ & -0.087 & -0.036 & $-0.026^{* *}$ \\
\hline & $(0.062)$ & $(0.077)$ & $(0.072)$ & $(0.066)$ & $(0.050)$ & $(0.010)$ \\
\hline \multirow[t]{2}{*}{ Potential experience } & $0.057^{* * *}$ & $0.053^{* * *}$ & $0.065^{* * *}$ & $0.043^{* * *}$ & $0.038^{* * *}$ & $0.003^{* *}$ \\
\hline & $(0.014)$ & $(0.012)$ & $(0.015)$ & $(0.014)$ & $(0.012)$ & $(0.001)$ \\
\hline \multirow[t]{2}{*}{ Sector tenure } & $-0.160^{* *}$ & 0.001 & -0.040 & $1.234^{* * *}$ & $0.201^{* * *}$ & $-0.017^{* *}$ \\
\hline & $(0.063)$ & $(0.076)$ & $(0.064)$ & $(0.064)$ & $(0.044)$ & $(0.007)$ \\
\hline \multirow[t]{2}{*}{ Informal $\times$ sector tenure } & 0.044 & -0.045 & 0.025 & -0.018 & $0.826^{* * *}$ & 0.007 \\
\hline & $(0.051)$ & $(0.054)$ & $(0.048)$ & $(0.054)$ & $(0.046)$ & $(0.005)$ \\
\hline \multirow[t]{2}{*}{ Informal } & $-0.925^{* * *}$ & $-0.520^{* * *}$ & $-1.021^{* * *}$ & $-0.890^{* * *}$ & $3.458^{* * *}$ & $-0.067^{* * *}$ \\
\hline & $(0.136)$ & $(0.141)$ & $(0.145)$ & $(0.143)$ & $(0.098)$ & $(0.020)$ \\
\hline \multirow[t]{2}{*}{ Employer 10} & 0.255 & 0.129 & 0.068 & $0.502^{* *}$ & $0.348^{* *}$ & $1.044^{* * *}$ \\
\hline & $(0.202)$ & $(0.203)$ & $(0.204)$ & $(0.206)$ & $(0.158)$ & $(0.022)$ \\
\hline \multirow[t]{2}{*}{ Married } & $1.085^{* * *}$ & $0.589^{* * *}$ & $1.255^{* * *}$ & $1.256^{* * *}$ & $0.519^{* * *}$ & $0.103^{* * *}$ \\
\hline & $(0.164)$ & $(0.174)$ & $(0.169)$ & $(0.166)$ & $(0.133)$ & $(0.018)$ \\
\hline \multirow[t]{2}{*}{ Education } & $-0.053^{*}$ & -0.019 & -0.020 & -0.047 & $-0.065^{* *}$ & -0.000 \\
\hline & $(0.029)$ & $(0.030)$ & $(0.030)$ & $(0.030)$ & $(0.027)$ & $(0.004)$ \\
\hline
\end{tabular}


Table 17 First-stage regressions: informal: based on medical benefits only (Continued)

\begin{tabular}{lllllll}
\hline Province unemployment & -0.026 & $0.107^{*}$ & 0.060 & 0.025 & 0.007 & $(0.060)$ \\
Rate & $(0.061)$ & $(0.058)$ & $(0.061)$ & 0.002 & $(0.044)$ \\
R-squared & 0.70 & 0.67 & 0.75 & 0.68 & 0.76 \\
F-statistic & 100.62 & 789.88 & 213.87 & 68.42 & 52.23 \\
\hline
\end{tabular}

Notes: Robust standard errors in parentheses; ${ }^{* * *} p<0.01,{ }^{* *} p<0.05,{ }^{*} p<0.1$. Second-stage results in Table 8 
Data and documentation for the IFLS can be found at: http://www.rand.org/labor/ FLS/IFLS.html.

The IFLS collects data to study a wide range of behaviors and outcomes for the Indonesian population. The IFLS is based on a sample of households representing about $83 \%$ of the Indonesian population living in 13 of the nation's 26 provinces in 1993. All of the provinces in the main islands of Java and Bali include Jakarta, West Java, Central Java, Yogyakarta, East Java, and Bali. The IFLS includes four provinces in Sumatra: North Sumatra, West Sumatra, South Sumatra, and Lampung. The remaining provinces are West Nusa Tenggara, South Kalimantan, and South Sulawesi. Other provinces were excluded because of prohibitive costs. Four surveys have been conducted in 1993, 1997, 2000, and 2007. The first wave (IFLS1) was administered in 1993 to individuals living in 7224 households, comprising over 22,000 individuals. The sampling approach in the subsequent waves of the IFLS was to re-contact all original IFLS1 households with living members the last time they had been contacted, plus split-off households from other waves. IFLS2 consists of 7620 households, and it succeeded in re-interviewing $94.4 \%$ of IFLS1 households. IFLS3 consists of 10,435 households; it re-contacted $95.3 \%$ of IFLS1 households. IFLS4 consists of 13,536 households; it re-contacted $93.6 \%$ of IFLS1 households. Nearly $91 \%$ of IFLS1 households were interviewed in all waves.

I. Employment types, industry, and occupation codes

1. Employment types

\begin{tabular}{ll}
\hline IFLS code & Employment type \\
1 & Self employed, no employee \\
2 & Self employed, with unpaid family workers/temporary workers \\
3 & Self employed, with permanent workers \\
4 & Government \\
5 & Private employee \\
6 & Unpaid family worker \\
7 & Casual worker, agriculture \\
8 & Casual worker, non-agriculture \\
\hline
\end{tabular}

In this paper, we categorize employment type into four categories as follows:

\begin{tabular}{ll}
\hline IFLS code & Employment type \\
1 & Self-employed \\
2 & Self-employed \\
3 & Self-employed \\
4 & Government \\
5 & Private employee \\
6 & Casual worker \\
7 & Casual worker \\
8 & Casual worker \\
\hline
\end{tabular}




\begin{tabular}{|c|c|}
\hline IFLS code & Industry \\
\hline 1 & Agriculture \\
\hline 2 & Mining \\
\hline 3 & Manufacturing \\
\hline 4 & Electricity gas water \\
\hline 5 & Construction \\
\hline 6 & Wholesale, retail, hotel \\
\hline 7 & Transportation, communication \\
\hline 8 & Finance, insurance, real estate \\
\hline 9 & Community, personal service \\
\hline 10 & Other \\
\hline \multicolumn{2}{|c|}{ 3. Occupation } \\
\hline IFLS code & Occupation \\
\hline OX or $1 X$ & Professional \\
\hline $2 X$ & Administrative/managerial \\
\hline $3 x$ & Clerical \\
\hline $4 X$ & Sales \\
\hline $5 X$ & Service \\
\hline $6 \mathrm{X}$ & Agriculture \\
\hline $7 X$ & Operation and production \\
\hline $8 x$ & Transportation operations \\
\hline $9 x$ & Blue collar \\
\hline M or MM & Military \\
\hline S or SS & Students \\
\hline
\end{tabular}

The IFLS originally used two-digit occupation codes but simplified the codes into one-digit occupation codes in waves 3 and 4. More detail on occupation list can be found in Appendix A of the IFLS1 documentation for household questionnaire.

II. Variable construction

Sample construction

We restrict the sample to respondents who were interviewed in at least two consecutive surveys. We further restrict the sample to males who ever worked between 1988 and 2007 and lived in an urban area in at least one round of the survey.

\section{Raw variables}

\section{Employment type}

We use the following variables on the respondent's primary job from each wave of the survey:

\begin{tabular}{lll}
\hline & Variable & Question \\
IFLS1 & TK24A & Which category best describes the work that you do? \\
IFLS2 & TK24A & Which category best describes the work that you do?
\end{tabular}


(Continued)

\begin{tabular}{lll}
\hline & Variable & Question \\
IFLS1 & TK24A & Which category best describes the work that you do? \\
IFLS2 & TK24A & Which category best describes the work that you do? \\
IFLS3 & TK24A & Which category best describes the work that you do? \\
IFLS4 & TK24A & Which category best describes the work that you do? \\
\hline
\end{tabular}

For labor force participation in non-survey years, we use the following retrospective variables:

\begin{tabular}{llll}
\hline & Variable & Interval & Question \\
IFLS1 & TK33 & $1988-1992$ & Which category best describes the work that you did? \\
IFLS2 & TK33 & $1988-1996$ & Which category best describes the work that you did? \\
IFLS3 & TK33 & $1996-1999$ & Which category best describes the work that you did? \\
IFLS4 & TK33 & $1999-2007$ & Which category best describes the work that you did? \\
\hline
\end{tabular}

\section{Employer tenure}

The following questions regarding tenure on the same job are asked retrospectively:

\begin{tabular}{|c|c|c|c|}
\hline & Variable & Interval & Question \\
\hline IFLS1 & TK29 & 1988-1992 & Was your primary job the same as the job in the year of $[\ldots]$ ? \\
\hline IFLS2 & TK29 & 1988-1996 & Was your primary job the same as the job in the year of $[\ldots]$ ? \\
\hline IFLS3 & TK29 & 1996-1999 & Was your primary job the same as the job in the year of $[\ldots]$ ? \\
\hline IFLS4 & TK30 & 1999-2007 & Where did you work? [Check if same employer as previous year] \\
\hline
\end{tabular}

Industry

We use the following variables on the respondent's primary job from each wave of the survey:

\begin{tabular}{lll}
\hline & Variable & Question \\
IFLS1 & TK19a_1 & What is manufactured/done at your workplace? \\
IFLS2 & TK20Aind & What is manufactured/done at your workplace? \\
IFLS3 & TK19Aa & In what field of work is this job? \\
IFLS4 & Tk19ab & What is manufactured/done at your workplace? \\
\hline
\end{tabular}

We use the following retrospective questions for non-survey years:

\begin{tabular}{llll}
\hline & Variable & Interval & Question \\
IFLS1 & TK31 & $1988-1992$ & What was manufactured/done at your workplace in the year of [...]? \\
IFLS2 & TK32ind & $1988-1996$ & What was manufactured/done at your workplace in the year of [...]? \\
IFLS3 & TK31Aa & $1996-1999$ & In what field of work was this job? \\
IFLS4 & TK31A & $1999-2007$ & Interviewer's note: Circle the appropriate field of work \\
\hline
\end{tabular}

Occupation

We use the following variables on the respondent's primary job from each wave of the survey:

\begin{tabular}{lll}
\hline & Variable & Question \\
IFLS1 & Occ12 & What are your primary duties at your workplace? \\
IFLS2 & TK20Aocc & What are your primary duties at your workplace? \\
IFLS3 & TK20Ab & Interviewer's note: Circle the appropriate code according to primary duties TK20A \\
IFLS4 & occ07tk2 & What are your primary duties at your workplace? \\
\hline
\end{tabular}


We use the following retrospective questions for non-survey years:

\begin{tabular}{llll}
\hline & Variable & Interval & Question \\
IFLS1 & TK32 & $1988-1992$ & What were your primary duties in the year of [...]? \\
IFLS2 & TK320cc & $1988-1996$ & What were your primary duties in the year of [...]? \\
IFLS3 & TK32B & $1996-1999$ & Interviewer's note: Circle the appropriate code according to primary duties TK32 \\
IFLS4 & Occ07 & $1999-2007$ & What were your primary duties in the year of [...]? \\
\hline
\end{tabular}

Other variables:

Primary job characteristics

We use the following variables on the respondent's primary job from each wave of the survey:

\begin{tabular}{|c|c|c|c|c|}
\hline & IFLS1 & IFLS2 & IFLS3 & IFLS4 \\
\hline Net salary last month & tk25r1_m & tk25amt & tk25a1 & tk25a1 \\
\hline Total monthly income & - & tk25am & - & - \\
\hline Net salary last year & tk25r1_y & tk25ayt & $\mathrm{tk} 25 \mathrm{a} 2$ & tk25a2 \\
\hline Total annual income & - & tk25ay & - & - \\
\hline Net profit last month & tk26r1_m & tk26amn & tk26amn & tk26a1 \\
\hline Gross profit, monthly & - & tk26amg & tk26amg & - \\
\hline Net profit last year & tk26r1_y & tk26ayn & tk26ayn & tk26a3 \\
\hline Gross profit, annual & - & tk26ayg & tk26ayg & - \\
\hline Health benefits & tk25a1_m & tk25ame & tk25a3e1 & tk25a3e1 \\
\hline Health insurance & - & - & tk25a3e2 & tk25a3e2 \\
\hline Health benefits: preferred clinic & - & - & tk25a3e3 & tk25a3e3 \\
\hline Number of workers & - & tk20aa & tk20aa & tk20aa \\
\hline Hours last week & tk21a & tk21a & tk21a & tk21a \\
\hline Usual hours worked & tk22a & $\mathrm{tk} 22 \mathrm{a}$ & tk22a & tk22a \\
\hline Weeks worked last year & tk23a & tk23a & tk23a & tk23a \\
\hline \multicolumn{5}{|c|}{ We use the following retrospective questions for non-survey years: } \\
\hline & IFLS1 & IFLS2 & IFLS3 & IFLS4 \\
\hline Monthly income & - & tk34t & tk34 & - \\
\hline Total monthly income & - & tk34 & - & - \\
\hline Monthly profit & - & tk35n & tk35n & - \\
\hline Gross income, monthly & - & tk35g & tk35g & - \\
\hline Hours worked/week & - & tk36 & tk36 & - \\
\hline Weeks worked/year & - & tk37 & tk37 & - \\
\hline Health benefits & - & tk34e & - & - \\
\hline
\end{tabular}

We use the consumer price index (CPI) published in the International Financial Statistics (IFS) to obtain real income. The IFS calculates CPI based on prices in 17 capital cities; this paper will use 2007 as the base year. We use real monthly wages, and net monthly profits for self-employed respondents, as income. If monthly income is not available, we use annual wages divided by 12 and annual profits divided by 12 for self-employed respondents. Hours per year is constructed based on normal hours worked multiplied by weeks worked. Real hourly wages is constructed using annual income divided by hours worked. We use log hourly wages in the analysis.

We recode response to the number of workers to match the categories in IFLS4. The range is as follows: 1 to 4 workers, 5 to 19 workers, 20 to 99 workers, and more than 100 . 


\section{Respondent characteristics}

Date of birth is asked every round of the survey; however, we find some inconsistencies in the responses across waves. First, we take the mean of the maximum and minimum of the mode of reported birth date and calculate respondent's age based on the constructed date of birth. If the difference between the maximum and minimum of the mode is more than 3 years, but the difference between any two of the reported dates of birth is less than 1 year, we use these closest dates of birth to calculate the mean of the birth date.

We define years of education as the maximum of the mode of reported years of education. Potential experience is defined as current age minus education minus 6 . We drop observations with negative potential experience.

2. Constructing tenure on the job, employment type, industry, and occupation

We reshape the data such that each observation is identified by respondent ID and year, instead of respondent ID and wave.

Imputations for job characteristics:

If occupation is missing but the industry is agriculture, we impute occupation to be casual worker. Similarly, if industry is missing but occupation is agriculture, we impute industry as agriculture. In more than $97 \%$ of cases where both occupation and industry are available, where occupation is agriculture, industry is agriculture and vice versa.

If respondents report being in the military, we impute the employment type to be government worker.

If respondents report having the same job but some characteristics (industry, occupation, or employment type) are missing, we assume the characteristics remain the same.

For each of the variables occupation, industry, and employment type, if one of them is missing but the two others are the same as in the previous or next year, then we assume that the missing variable also stays the same. This is not problematic for occupation and industry because in non-missing cases, the concordance is more than $98 \%$. For employment type, the concordance is still very high $(90 \%)$ but not quite as high.

We set the same job indicator to zero for the first year of work. We also set the same job indicator to zero if there is a major job characteristics change (a change in occupation is not considered a major change).

The number of workers is only asked in survey years. If the number of workers does not change within a job, we use the reported category of firm size to impute firm size for non-survey years. If the number of workers changed within a job, we use the reported firm size in the survey year as the firm size. In this case, we assume firm size does not change in between survey years.

We assume health benefits do not change within a job. Health benefits may be insurance, medical allowance, or the availability of a preferred provider. If reported health benefits are inconsistent within one job, we impute health benefits based on the previous or next year's reported status.

Tenure variables

We increase tenure on the job so long as the same job indicator is equal to one. If we have more than 3 consecutive years of missing indicator, we set the indicator to missing since we do not know the tenure. We may be underestimating tenure without imputation. 
For tenure on employment type, industry and occupation, we use the user-defined command tsspell ${ }^{10}$ to count the spell number and sequence number. This command takes into account the panel structure of the data. Similarly, if there are 3 or more missing values, we count tenure as missing.

Definitions of informality

Variable med1

Workers with any health benefits are considered formal.

Variable inf1

We define self-employment as informal. ${ }^{11}$ Government workers and those in the military are considered formal. Casual workers and workers in firms with fewer than 20 workers are considered informal. ${ }^{12}$

Variable infM

We take the definition based on medical benefits as in med1 and supplement the information with inf1.

Variable infM2

We refine our definition based on infM by separating self-employed workers.

Variable inf2

We refine our definition of informality based on inf1 into informal self-employed, informal not self-employed, and formal workers.

Variable inf2_big

We refine our definition of informality based on inf2 and assume all firms with fewer than 100 workers are informal.

Competing interests

The IZA Journal of Labor \& Development is committed to the IZA Guiding Principles of Research Integrity. The authors declare that they have observed these principles.

\section{Acknowledgements}

We would like to thank Joe Altonji and Murray Leibbrandt for their helpful comments on our paper. We would also like to thank the seminar participants at the University of Chicago Harris School of Public Policy, 9th IZA/World Bank Conference on Employment and Development conference, and the Population Association of America 2014 annual meeting.

Responsible editor: Hartmut F. Lehmann

\section{Author details}

${ }^{1}$ University of Chicago, 1155 E. 60th St, Chicago, IL 60637, USA. ${ }^{2}$ Nanyang Technological University, 14 Nanyang Drive, Singapore, Singapore.

Received: 30 July 2015 Accepted: 7 January 2016

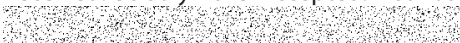

References

Altonji JG, Shakotko RA (1987) Do wages rise with job seniority? Rev Econ Stud 54(3):437-460

Altonji JG, Williams N (1998) The effects of labor market experience, job seniority, and job mobility on wage growth. Res Labor Econ 17:233-276

Altonji JG, Williams N (2005) "Do wages rise with job seniority? A reassessment." Industrial \&Labor Relations Review 58, no. 3(2005):370-397

Angelini J, Hirose K (2004) Extension of social security coverage for the informal economy in Indonesia: surveys in the urban and rural informal economy. International Labour Organization

Bacchetta M, Ernst E, Bustamante JP (2009) Globalization and informal jobs in developing countries. International Labour Organization, Geneva

Becker GS (1964) Human capital: a theoretical analysis with special reference to education. National Bureau for Economic Research, Columbia University Press, New York and London

Beffy M, Buchinsky M, Fougère D, Kamionka T, Kramarz F (2006) The returns to seniority in France (and why are they lower than in the United States?), IZA Discussion Paper No. 1935

Blau DM (1985) Self-employment and self-selection in developing country labor markets. South Econ J 52:351-363

Dustmann C, Pereira SC (2005) Wage Growth and Job Mobility in the U.K. and Germany. IZA Discussion Paper No. 1586. Available at SSRN: http://ssrn.com/abstract=721901. 
Dustmann C, Pereira SC (2007) Wage growth and job mobility in the United Kingdom and Germany. Indus \& Lab Rel Rev 61:374

Kambourov G, Manovskii I (2009) Occupational specificity of human capital*. Int Econ Rev 50(1):63-115

Lagakos D, Moll B, Porzio T, Qian N (2012) Experience matters: human capital and development accounting, No. w18602. National Bureau of Economic Research

Maloney WF (1999) Does informality imply segmentation in urban labor markets? Evidence from sectoral transitions in Mexico. World Bank Econ Rev 13(2):275-302

Maloney WF (2004) Informality revisited. World Dev 32(7):1159-1178

Mammen K, Paxson C (2000) Women's work and economic development. J Econ Perspect 14:141-164

Parent D (2000) Industry-specific capital and the wage profile: evidence from the national longitudinal survey of youth and the panel study of income dynamics. J Labor Econ 18(2):306-323

Perry GE, Maloney WF, Arias OS, Fajnzylber P, Mason AD, Saavedra-Chanduvi J (2007) Informality: Exit and Exclusion, World Bank Latin America and Caribbean Studies." World Bank, Washington DC

Rosenzweig MR (1988) Labor markets in low-income countries. Handb Dev Econ 1:713-762

Setiana A (2010) Social health insurance development as an integral part of the national health policy: recent reform in Indonesian health insurance system. In: International Conference on Social Health Insurance in Developing Countries, Berlin. pp 5-7

Sullivan P (2010) Empirical evidence on occupation and industry specific human capital. Labour Econ 17(3):567-580

Topel RH (1991) Specific capital, mobility, and wages: wages rise with job seniority. J Polit Econ 99:145-176

Yamada G (1996) Urban informal employment and self-employment in developing countries: theory and evidence. Econ Dev Cult Chang 44(2):289-314

Submit your manuscript to a SpringerOpen ${ }^{\circ}$ journal and benefit from:

- Convenient online submission

- Rigorous peer review

- Immediate publication on acceptance

- Open access: articles freely available online

- High visibility within the field

Retaining the copyright to your article

Submit your next manuscript at $\gg$ springeropen.com 